\title{
Observations of heterogeneous reactions between Asian pollution and mineral dust over the Eastern North Pacific during INTEX-B
}

\author{
C. S. McNaughton ${ }^{1}$, A. D. Clarke ${ }^{1}$, V. Kapustin ${ }^{1}$, Y. Shinozuka ${ }^{1}{ }^{*}$, S. G. Howell ${ }^{1}$, B. E. Anderson ${ }^{2}$, E. Winstead ${ }^{2}$, \\ J. Dibb ${ }^{3}$, E. Scheuer ${ }^{3}$, R. C. Cohen ${ }^{4}$, P. Wooldridge ${ }^{4}$, A. Perring ${ }^{4}$, L. G. Huey ${ }^{5}$, S. Kim ${ }^{5}$, J. L. Jimenez ${ }^{6}$, E. J. Dunlea ${ }^{6}$, \\ P. F. DeCarlo ${ }^{6, * *}$, P. O. Wennberg ${ }^{7}$, J. D. Crounse ${ }^{7}$, A. J. Weinheimer ${ }^{8}$, and F. Flocke ${ }^{8}$ \\ ${ }^{1}$ School of Ocean and Earth Science and Technology, University of Hawaii, Honolulu, 96822 HI, USA \\ ${ }^{2}$ NASA Langley Research Center, Hampton, 23665 VA, USA \\ ${ }^{3}$ University of New Hampshire, Durham, $03824 \mathrm{NH}$, USA \\ ${ }^{4}$ University of California Berkeley, Berkeley, 94720 CA, USA \\ ${ }^{5}$ Georgia Institute of Technology, Atlanta, 30332 GA, USA \\ ${ }^{6}$ Cooperative Institute for Research in Environmental Sciences (CIRES) and University of Colorado, Boulder, \\ 80309 CO, USA \\ ${ }^{7}$ California Institute of Technology, Pasadena, 91125 CA, USA \\ ${ }^{8}$ National Center for Atmospheric Research, Boulder, 80307 CO, USA \\ *now at: NASA Ames Research Center, Moffett Field, 94035 CA, USA \\ ***now at: Paul Scherrer Institute, 5232 Villigen-PSI, Switzerland
}

Received: 19 Februar 2009 - Published in Atmos. Chem. Phys. Discuss.: 31 March 2009

Revised: 11 September 2009 - Accepted: 15 September 2009 - Published: 3 November 2009

\begin{abstract}
In-situ airborne measurements of trace gases, aerosol size distributions, chemistry and optical properties were conducted over Mexico and the Eastern North Pacific during MILAGRO and INTEX-B. Heterogeneous reactions between secondary aerosol precursor gases and mineral dust lead to sequestration of sulfur, nitrogen and chlorine in the supermicrometer particulate size range.

Simultaneous measurements of aerosol size distributions and weak-acid soluble calcium result in an estimate of $11 \mathrm{wt} \%$ of $\mathrm{CaCO}_{3}$ for Asian dust. During transport across the North Pacific, $~ 5-30 \%$ of the $\mathrm{CaCO}_{3}$ is converted to $\mathrm{CaSO}_{4}$ or $\mathrm{Ca}\left(\mathrm{NO}_{3}\right)_{2}$ with an additional $\sim 4 \%$ consumed through reactions with $\mathrm{HCl}$. The 1996 to 2008 record from the Mauna Loa Observatory confirm these findings, indicating that, on average, $19 \%$ of the $\mathrm{CaCO}_{3}$ has reacted to form $\mathrm{CaSO}_{4}$ and $7 \%$ has reacted to form $\mathrm{Ca}\left(\mathrm{NO}_{3}\right)_{2}$ and $\sim 2 \%$ has reacted with $\mathrm{HCl}$. In the nitrogen-oxide rich boundary layer near Mexico City up to $30 \%$ of the $\mathrm{CaCO}_{3}$ has reacted to form $\mathrm{Ca}\left(\mathrm{NO}_{3}\right)_{2}$ while an additional $8 \%$ has reacted with $\mathrm{HCl}$.

These heterogeneous reactions can result in a $\sim 3 \%$ increase in dust solubility which has an insignificant effect on
\end{abstract}

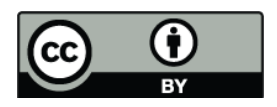

Correspondence to: C. S. McNaughton (csmcnaug@hawaii.edu) their optical properties compared to their variability in-situ. However, competition between supermicrometer dust and submicrometer primary aerosol for condensing secondary aerosol species led to a $25 \%$ smaller number median diameter for the accumulation mode aerosol. A $10-25 \%$ reduction of accumulation mode number median diameter results in a 30-70\% reduction in submicrometer light scattering at relative humidities in the $80-95 \%$ range. At $80 \% \mathrm{RH}$ submicrometer light scattering is only reduced $\sim 3 \%$ due to a higher mass fraction of hydrophobic refractory components in the dust-affected accumulation mode aerosol. Thus reducing the geometric mean diameter of the submicrometer aerosol has a much larger effect on aerosol optical properties than changes to the hygroscopic:hydrophobic mass fractions of the accumulation mode aerosol.

In the presence of dust, nitric acid concentrations are reduced to $<50 \%$ of total nitrate (nitric acid plus particulate nitrate). $\mathrm{NO}_{\mathrm{y}}$ as a fraction of total nitrogen $\left(\mathrm{NO}_{\mathrm{y}}\right.$ plus particulate nitrate), is reduced from $>85 \%$ to $60-80 \%$ in the presence of dust. These observations support previous model studies which predict irreversible sequestration of reactive nitrogen species through heterogeneous reactions with mineral dust during long-range transport.

Published by Copernicus Publications on behalf of the European Geosciences Union. 


\section{Introduction}

Mineral aerosol is generated at the Earth surface by aeolian erosion of unconsolidated sand to clay grade soil particles. Under specific meteorological conditions, large dust storms can loft mineral dust directly into the FT where they can be transported intercontinentally (Clarke et al., 2001; Husar et al., 2001; Prospero, 1999).

Mineral aerosol participate in a wide variety of atmospheric process including direct radiative forcing (Sokolik and Toon, 1999; Tegen and Lacis, 1996), indirectly as cloud and ice condensation nuclei (Charlson et al., 1992; Sassen, 2002; Sassen et al., 2003), as a source of micronutrients in biogeochemical cycles (Harvey, 2007; Martin, 1990), and as surfaces for heterogeneous chemical reactions (Andreae and Crutzen, 1997; Dentener et al., 1996; Song and Carmichael, 2001). Laboratory measurements have shown that metal oxides (e.g. $\mathrm{CaO}, \mathrm{MgO})$ as well as carbonates $\left(\mathrm{CaCO}_{3}\right)$ in African and Asian dust samples can facilitate the oxidation of $\mathrm{SO}_{\mathrm{x}}$ (Ullerstam et al., 2002; Usher et al., 2002), $\mathrm{NO}_{\mathrm{x}}$ (Grassian, 2001; Underwood et al., 2001) and serve as a sink for chlorine (Murphy et al., 2006; Sullivan et al., 2007b). Climate models are incorporating these heterogeneous reactions because they irreversibly transfer these species from the gas- to the particulate-phase (Phadnis and Carmichael, 2000; Song and Carmichael, 2001), affecting the concentrations of tropospheric oxidants (Jacob, 2000; Martin et al., 2003; Tang et al., 2004) and global radiative forcing (Bauer and Koch, 2005; Liao and Seinfeld, 2005).

Estimates of present day dust emissions fluxes are on the order of 1000-3000 $\mathrm{Tg} \mathrm{yr}^{-1}$ (Dentener et al., 1996, 2006; Ginoux et al., 2001). The total all-models-average for the global climate models (GCMs) participating in the AeroCom project is $1840 \mathrm{Tg} \mathrm{yr}^{-1}$ with a total model diversity ${ }^{1}$, $\delta$, of $49 \%$ (Textor et al., 2006). The AeroCom GCMs estimate that wet removal accounts for $32 \%$ of total removal, though there is considerable variability between the models $(\delta=54 \%)$. The mean atmospheric residence times are on the order of 4 days $(\delta=43 \%)$ resulting in a mean estimate of global annual average aerosol dust burden of $20 \mathrm{Tg}$ $(\delta=40 \%)$. AeroCom simulations of mineral dust indicate this aerosol accounts for $\sim 70 \%$ of the global annual average dry aerosol mass. However, dust accounts for only $25 \%$ of global annually average aerosol optical depth (AOT), a value comparable in magnitude to hygroscopic aerosol such as sulfates and sea salt (Kinne et al., 2006).

The Chinese "Loess plateau" is the world's largest deposit of loess; a sedimentary deposit of wind blown siltand clay-grade material. The loess-paleosol sequence of the Loess plateau has a relatively continuous depositional character over the past 2.4-2.6 million years (Liu, 1985). Re-

\footnotetext{
${ }^{1}$ Total model diversity, $\delta$, is computed as the standard deviation of the model values normalized by the all-models average and expressed as a percentage.
}

cent work potentially extends the geological time scale of its formation to $\sim 7.0$ million years (Ding et al., 2001). Electron microscope analysis of Chinese Loess show that the upper part of the stratigraphy is comprised of a meta-stable microfabric of plate-like aliminosilicates $(\sim>70 \mathrm{wt} \%)$ (Derbyshire, 1983; Ding et al., 2001; Liu, 1985). Aluminosilicates in the clay size fraction $(<6.0 \mu \mathrm{m})$ of Chinese Loess are composed mostly of illite, kaolinite and montmorillinite (Liu, 1985). Calcite is the fourth most abundant mineral in the clay size fraction $(<6 \mu \mathrm{m})$ but is also the most variable. During suspension $\mathrm{Ca} / \mathrm{Al}$ ratios in Asian dust are depleted compared to the parent materials while $\mathrm{Fe} / \mathrm{Al}$ ratios are relatively well conserved (Arimoto et al., 2006 and refs). Iron oxides constitute $\sim 3-6 \mathrm{wt} \%$, and are typically surface bound to the clay grade minerals accounting for $\sim 50 \%$ of the total iron $\left(\mathrm{Fe}_{2} \mathrm{O}_{3}\right)$. Goethite and hematite account for $75 \%$ and $25 \%(+/-10 \%)$ of the iron oxides respectively and are the only two minerals responsible for visible light absorption by Asian dust (Lafon et al., 2006). Laboratory tests of water adsorption indicate no more than 3-4 monolayers of $\mathrm{H}_{2} \mathrm{O}$ on the surface of these minerals under typical atmospheric conditions (Grassian, 2001 and refs). $\mathrm{HNO}_{3}$ and $\mathrm{NO}_{2}$ will adsorb directly onto metal oxides $\left(\mathrm{Al}_{2} \mathrm{O}_{3}, \mathrm{Fe}_{2} \mathrm{O}_{3}, \mathrm{TiO}_{2}, \mathrm{CaO}\right.$ and $\mathrm{MgO}$ ) with the notable exception of $\mathrm{SiO}_{2}$. The presence of adsorbed water greatly enhances the $\mathrm{NO}_{2}$ and $\mathrm{HNO}_{3}$ uptake coefficients compared to dry conditions. However reactions between $\mathrm{NO}_{2}$ and $\mathrm{HNO}_{3}$ with $\mathrm{Al}_{2} \mathrm{O}_{3}, \mathrm{Fe}_{2} \mathrm{O}_{3}$ and $\mathrm{TiO}_{2}$ are surface limited, i.e. there is no reaction with internal crystal structure, whereas the reactions with $\mathrm{CaO}, \mathrm{MgO}$, and especially $\mathrm{CaCO}_{3}$, occur throughout the bulk particle (Grassian, 2001).

The recognition that anthropogenic secondary aerosol precursors (e.g. $\mathrm{SO}_{2}, \mathrm{NO}_{2}$ and $\mathrm{HNO}_{3}$ ) can react with natural mineral aerosol, has led to several model studies designed to evaluate the effects of heterogeneous chemical reactions on aerosol direct and indirect effects (Bauer et al., 2007; Fan et al., 2004; Tang et al., 2004). Heterogeneous reactions were found to increase wet deposition of dust near the Asian source regions resulting in up to a $50 \%$ decrease in deposition over the Eastern North Pacific (Fan et al., 2004). Citing Lammel and Novakov (1995) as well as Wyslouzil et al. (1994), Bauer et al. (2007) assumed dust particles with a $10 \%$ surface coating of sulfate or nitrate behaved as if they were completely soluble. The studies cited are hardly applicable to the formation of "soluble dust", as they investigated the coating of homogeneous, hydrophobic, primary soot with soluble sulfate and nitrate species. However, based on this assumption, Bauer et al. (2007) conclude that enhanced wet deposition of "soluble dust" leads to a $20 \%$ reduction (33.5 vs. $41.6 \mathrm{Tg}$ ) in the present-day global annual dust budget, compared to simulations that omit heterogeneous reactions.

Particles with diameters greater than $\sim 2 \mu \mathrm{m}$ activate regardless of composition for supersaturations typical of continental and marine cumulus cloud $(\sim 0.2 \%)$ (Kelly et al., 2007). At $0.2 \%$ supersaturation $\mathrm{CaCO}_{3}$ and $\mathrm{SiO}_{2}$ with a 
$1 \%$ coating of gypsum, will activate if they have dry diameters greater than $\sim 1 \mu \mathrm{m}$. Activation of "completely insoluble" dust particles in the $0.6-2.0 \mu \mathrm{m}$ size range is facilitated by the presence of slightly soluble compounds (Kelly et al., 2007). These findings are supported by field measurements which show that calcite-containing particulate are acting as CCN (Matsuki et al., 2009; Twohy et al., 2009). The size, composition and mixing state of dust particles will codetermine their effectiveness as ice nuclei (IN). At $-10^{\circ} \mathrm{C}$ to $-40^{\circ} \mathrm{C}$ and relative humidity with respect to ice $\left(\mathrm{RH}_{i}\right)$ of $110-135 \%$, kaolinite, illite, muscovite and hematite are the most efficient IN while montmorillonite, quartz, calcite and gypsum are the poorest IN (Eastwood et al., 2008; Zimmermann et al., 2008). Eastwood et al. (2009) recently determined that heterogeneous reactions can inhibit the icenucleating ability of kaolinite. Whereas a separate study (Archuleta et al., 2005) found that Asian dust particles larger than $\sim 0.2 \mu \mathrm{m}$ are all effective cirrus cloud ice nuclei at $\mathrm{RH}_{i}$ of $\sim 135 \%$ irrespective of temperature.

Given the difficulty in simulating relative humidity (Petch, 2001) and aerosol indirect effects using GCM's (Penner et al., 2006), it is difficult to have confidence in recent model estimates of the influence of heterogeneous chemical reactions on atmospheric residence times of mineral dust. In their 2007 work, Bauer et al. (2007) calculate a 20\% reduction in present-day dust burden compared to pre-industrial values ( 33.5 vs. $41.8 \mathrm{Tg}$ ) when heterogeneous chemical reactions are considered in both simulations. Present-day versus pre-industrial simulations should potentially include emissions of primary urban dust (Alfaro et al., 2003; Cohen et al., 2004), soil dust from agricultural activities (Sokolik and Toon, 1996; Tegen and Fung, 1995; Tegen et al., 2004), and dust emissions due to anthropogenically-induced desertification (Chen et al., 1999; Moulin and Chiapello, 2006; Sheehy, 1992). Furthermore, short model integration times (e.g. 6 years in Bauer et al.) cannot capture inter-decadal variability in precipitation and vegetative cover; which likely exerts a controlling influence on dust generation (Dai et al., 1997; Nicholson et al., 1998). The absence of dynamic aerosol size distributions with size resolved, and source-dependent, mineral compositions in GCM's mean that recent comparisons between pre-industrial versus contemporary dust burdens are likely an over-simplification.

Here we use in-situ airborne measurements of trace gases, aerosol microphysics and chemistry to evaluate the potential for heterogeneous chemical reactions between Asian pollution and Asian dust to influence aerosol optical properties over the Eastern North Pacific. We include an analysis of the heavily polluted continental boundary layer (CBL) and free troposphere (FT) near Mexico City, as well as longterm measurements at the Mauna Loa Observatory (MLO) in Hawaii. These results are then discussed with regard to modeling studies in order to evaluate model assumptions and the plausibility of some of their conclusions regarding heterogeneous reactions occurring on mineral dust particulate, their effect on aerosol optical properties, and the partitioning of reactive species between the gas and aerosol phases.

\section{In-situ sampling of tropospheric aerosols during INTEX-B}

During spring of 2006 the NASA DC-8 participated in Phase $\mathrm{B}$ of the Intercontinental Chemical Transport Experiment (INTEX-B), also a component of the Megacities Initiative: Local and Global Research Observations experiment (MILAGRO) (Molina et al., 2008; Singh et al., 2009). The NSF/NCAR C-130 participated in MILAGRO and the Pacific phase of INTEX-B with funding provided by the US National Science Foundation (NSF). During March of 2006 both aircraft were used to characterize the near-field trace gases and aerosols from the Central Mexican Plateau and their regional transport out over the Gulf of Mexico. During the last two weeks of April and the first two weeks of May 2006 the DC-8 was stationed in Honolulu, Hawaii and then Anchorage, Alaska while the NSF/NCAR C-130 was stationed in Seattle, Washington. During this period both aircraft sampled the marine boundary layer and free troposphere to study the long-range transport of Asian pollution and dust to the west coast of North America.

A detailed review of the meteorological setting during the measurements over Mexico can be found in Fast et al. (2007). The Hawaii phase of INTEX-B was climatologically average while the Alaskan phase of INTEX-B was climatologically "wet" with more frequent than average occurrence of lowpressure cyclonic weather systems in the North Pacific $(\mathrm{H}$. Fuelberg, personal communication, 2007).

\subsection{In-situ measurements of aerosol size distributions}

Aboard the NASA DC- 8 the University of Hawaii solid diffuser inlet (UH inlet) delivers ambient air to the combined NASA Langley Research Center (LaRC) and Hawaii Group for Environmental Aerosol Research (HiGEAR) aerosol sampling package. Sample air is delivered to the University of New Hampshire's (UNH) filter-based aerosol chemistry system via the UNH solid diffuser inlet. Supermicrometer aerosol passing efficiencies were recently evaluated for these two inlets over the performance envelope of the NASA DC-8 (McNaughton et al., 2007). Aboard the NSF/NCAR C-130 sample air is delivered to the HiGEAR instrument package via a solid diffuser inlet evaluated during PELTI (Huebert et al., 2004).

Total and refractory (residence time, $\tau=0.1 \mathrm{~s} @ 360^{\circ} \mathrm{C}$ ) aerosol number $(\mathrm{Dp}>10 \mathrm{~nm})$ are measured using two TSI model 3010 condensation nuclei counters (Clarke et al., 1997). Custom built differential mobility analyzers (DMA) are used to measure aerosol size distributions over the $d_{m}=0.010-0.20 \mu \mathrm{m}$ size range aboard both aircraft. The DMAs are equipped with a lagged aerosol grab sampler 
(LAG chamber) (Clarke et al., 1998). Each DMA system is also equipped with a heater assembly or, thermo-optical aerosol discriminator (TOAD), which pre-heats the aerosol to $150^{\circ} \mathrm{C}$ or $300^{\circ} \mathrm{C}(\tau=0.2 \mathrm{~s})$ prior to analysis (Clarke, 1991). In polluted airmasses the internally mixed refractory aerosol is commonly comprised of the "soot" components responsible for light absorption (Clarke et al., 2004, 2007; Mayol-Bracero et al., 2002). Preheating the aerosol does not affect the analysis of sea salt or dust, the most common natural refractory primary aerosol species. During INTEX-B the DC-8 aerosol package was equipped with an additional "long" DMA (LDMA, $d_{m}=0.01-0.50 \mu \mathrm{m}$ ) and employed a smaller mini-LAG chamber but no TOAD. The MILAGRO C-130 did not contain an additional LDMA unit.

Both aircraft were equipped with a custom modified PMS LAS-X optical particle counter used to measure the aerosol size distribution between $d_{o e}=0.1$ and $20.0 \mu \mathrm{m}$ at a size resolution of 112 channels per logarithmic decade. Each OPC is equipped with a 4-channel TOAD assembly operating at dry ${ }^{2}$ ambient temperature, $150^{\circ} \mathrm{C}, 300^{\circ} \mathrm{C}$ and $420^{\circ} \mathrm{C}$ ( $\tau=2.0 \mathrm{~s}$ ) (Clarke et al., 2007). The OPC's are calibrated using monodisperse polystyrene spheres with a density of $1.05 \mathrm{~g} \mathrm{~cm}^{-3}$ and a refractive index of $1.59 @ 589 \mathrm{~nm}$. OPC sizing accuracy is also evaluated using borosilicate glass beads with a density of $2.52 \mathrm{~g} \mathrm{~cm}^{-3}$ and a refractive index of $1.56 @ 589 \mathrm{~nm}$, and silicon dioxide $\left(\mathrm{SiO}_{2}\right)$ spheres with a density of $2.01 \mathrm{~g} \mathrm{~cm}^{-3}$ and a refractive index of $1.40 @ 589 \mathrm{~nm}$. The aerosol size determined by the OPC instrument are optically effective diameters $\left(d_{o e}\right)$ as discussed in Clarke et al. (2004). During post-processing the unheated OPC size distributions are adjusted to $d_{g}$, to account for sizing errors due to aerosol refractive indices that differ from those of the PSL calibration spheres (1.59 @ $589 \mathrm{~nm}$ ). OPC sizes over the $0.12-0.53 \mu \mathrm{m}$ size range are adjusted assuming an ammonium sulfate composition with a refractive index of $1.53-0.0 \mathrm{i}$. When sampling mineral dust the OPC sizes over the size range $0.53-8.0 \mu \mathrm{m}$ are adjusted assuming a refractive index of 1.53-0.0006i. When sampling sea salt aerosol no size adjustment is made to the data in the 0.53 $8.0 \mu \mathrm{m}$ size range because the dry sea salt refractive index $(1.588-0.0 \mathrm{i})$ is close to that of PSL (1.59-0.0i) at the He-Ne laser wavelength of $633 \mathrm{~nm}$. No optical to geometric size adjustments are made for the heated OPC channels as information regarding chemical composition, and thus refractive index, is a relative unknown. Counting statistics and sizing accuracy of the OPC is typically poor beyond $8.0 \mu \mathrm{m}$, thus data above this size range is typically eliminated from the data sets.

Aerodynamic aerosol size distributions in the $d_{a e}=0.5$ $20.0 \mu \mathrm{m}$ size range are measured using a TSI model 3321 aerodynamic particle sizer (APS). APS flow and sizing calibrations were routinely performed according to the procedures outlined in McNaughton et al. (2007). Data from

\footnotetext{
${ }^{2}$ ram heating plus $50 \%$ dilution with desiccated air.
}

the first five channels $(0.50-0.78 \mu \mathrm{m})$ were discarded due to poor instrument performance over this size range. Ignoring slip correction factors $\left(\mathrm{C}_{c, a e} / \mathrm{C}_{c, g}\right)$ by approximating them as unity, aerodynamic diameters $\left(d_{a e}\right)$ were adjusted to geometric diameters $\left(d_{g}\right)$ during post processing (Baron and Willeke, 2001; DeCarlo et al., 2004). We assume a dry bulk density of $2.06 \mathrm{~g} \mathrm{~cm}^{-3}$ for Chinese loess (Liu, 1985). This bulk density is used to correct supermicrometer mineral aerosol aerodynamic to geometric diameters and when converting aerosol volume to mass and vice versa. This is equivalent to assigning a shape factor, $\chi$, of 1.10-1.25 for dust particles with aerodynamic diameters between 0.5 and $10.0 \mu \mathrm{m}$ assuming a bulk density for crustal material of $2.56 \mathrm{~g} \mathrm{~cm}^{-3}$ (Craig., 1997). The loess value $\left(2.06 \mathrm{~g} \mathrm{~cm}^{-3}\right)$ is nearly identical to the "effective density" of $2.0 \mathrm{~g} \mathrm{~cm}^{-3}$ proposed by Reid et al. (2003) but smaller than the value used in McNaughton et al. (2007) to evaluate DC-8 inlet passing efficiencies. When recalculated, the $50 \%$ passing efficiency diameters of the UH and UNH inlets are no less than $3.5 \mu \mathrm{m}$ and $2.8 \mu \mathrm{m}$ when sampling Asian dust at the surface and $2.2 \mu \mathrm{m}$ and $1.8 \mu \mathrm{m}$ when sampling at the DC-8 ceiling of $12 \mathrm{~km}$.

\subsection{In-situ measurements of aerosol optical properties}

Total aerosol light scattering is measured aboard each aircraft using TSI model 3563, 3-wavelength $(3-\lambda)$ integrating nephelometers (TSI-Neph) (Anderson et al., 1996; Anderson and Ogren, 1998). Submicrometer aerosol light scattering is measured using Radiance Research model 903 singlewavelength nephelometers (RR-Neph). The Anderson and Ogren (1998) truncation correction has been applied to the TSI-Neph data while the empirically derived truncation correction of Anderson et al. (2003) has been applied to the RR Neph data. Calibrations using filtered $\mathrm{CO}_{2}$ and Refrigerant 134A were performed prior to each deployment and every $3-$ 5 flights. No significant $(<5 \%)$ calibration adjustments were required for the TSI-Nephs while slight (5-10\%) adjustments were often required for the zero and span of the RR-Nephs. During each flight at least one 300-s filtered air sample was collected to check for leaks and/or deviations from zero. Accuracy $(+/-2 \%)$ and precision $\left(0.2 \mathrm{Mm}^{-1}\right.$ for $300 \mathrm{~s}$ average $)$ estimates for these instruments are comparable to those determined previously (Anderson et al., 2003; Anderson and Ogren, 1998).

Total and submicrometer aerosol absorption is measured using Radiance Research 3- $\lambda$ particle soot absorption photometers (PSAP) corrected according to Virkkula et al. (2005). In laboratory tests prior to the MILAGRO and INTEX-B experiment three of the four 3- $\lambda$ PSAPs were tested for instrument noise while sampling filtered air. The average instrument noise $\left(\delta_{300}\right)$ is computed as the average standard deviation for six, $300 \mathrm{~s}$ (5-min) averages of the 1$\mathrm{Hz}$ data (Table 1). These values are comparable to instrument noise $\left(\delta_{240}=0.72 \mathrm{Mm}^{-1}\right.$ and $\left.0.33 \mathrm{Mm}^{-1}\right)$ reported for 
Table 1. Laboratory comparison of PSAP instrument noise while sampling filtered air.

\begin{tabular}{lllllll}
\hline Unit & Owner & Experiment & $\begin{array}{l}\text { Total or Submicrometer } \\
\text { Sampling }\end{array}$ & $\begin{array}{l}\text { Blue } \delta_{300} \\
\left(\mathrm{Mm}^{-1}\right)\end{array}$ & $\begin{array}{l}\text { Green } \delta_{300} \\
\left(\mathrm{Mm}^{-1}\right)\end{array}$ & $\begin{array}{l}\text { Red } \delta_{300} \\
\left(\mathrm{Mm}^{-1}\right)\end{array}$ \\
\hline PSAP1 & HiGEAR & INTEX-NA \& MILAGRO & Total & 0.56 & 0.56 & 0.56 \\
PSAP2 & LaRC & INTEX-B & Total & 0.36 & 0.34 & 0.36 \\
PSAP3 & LaRC & INTEX-B & submicrometer & 0.51 & 0.50 & 0.55 \\
PSAP4 & HiGEAR & MILAGRO & submicrometer & & & \\
\hline
\end{tabular}

the single-wavelength PSAPs used to measure total and submicrometer absorption during ACE-Asia (Anderson et al., 2003). PSAP \#4 was not delivered from the manufacturer until after the November 2005 intercomparison. Note that while instrument noise and thus precision of the PSAP's can be assessed, we have no way to calibrate the instruments for absolute accuracy. During MILAGRO and INTEX-B there were three intercomparison flights where the NASA DC-8 and the NSF/NCAR C-130 flew in formation. Total and submicrometer aerosol absorption was comparable during these time periods (not shown). Small discrepancies due to flow rate calibrations and errors in filter spot sizes have been corrected.

Two RR-Nephs are used to measure aerosol $\mathrm{f}(\mathrm{RH})$ between $80 \%$ and $40 \% \mathrm{RH}$ at a wavelength of $532 \mathrm{~nm}$. Air sampled by one nephelometer (RRwet) is preconditioned to a relative humidity of $80 \%+/-7 \%$ using a custom designed $\mathrm{f}(\mathrm{RH})$ system employing a GORE-TEX ${ }^{T M}$ membrane. The second nephelometer (RRdry) was plumbed in parallel and outfitted with a commercial blanket heater. The blanket heater raises the nephelometer temperature by $5-10^{\circ} \mathrm{C}$ reducing the relative humidity to values below $40 \%$ in the humid $\left(\mathrm{RH}_{a m b}>90 \%\right)$ marine boundary layer and often below $5 \%$ in the free troposphere. This heating may cause minor evaporation of non-refractory species of the order of a several percent of the mass of organic species and ammonium nitrate (Huffman et al., 2008). Using the corrected scattering values and RH recorded by the RRdry and RRwet nephelometers, a two point fit is used to compute $\gamma$, the exponential term in the $\mathrm{f}(\mathrm{RH})$ equation:

$\sigma_{\mathrm{sp}, \mathrm{amb}}=\sigma_{\mathrm{sp}, \mathrm{dry}} \times\left(\frac{1-\frac{\mathrm{RH}_{\mathrm{dry}}}{100}}{1-\frac{\mathrm{RH}_{\mathrm{amb}}}{100}}\right)^{\gamma}$

where, $\sigma_{\mathrm{sp}, \text { dry }}$ and $\sigma_{\mathrm{sp}, \text { amb }}$ are light scattering at the indicated "dry" and "ambient" relative humidities (Carrico et al., 2003; Howell et al., 2006).

A ground-based test of the $\mathrm{f}(\mathrm{RH})$ system was performed in its flight configuration aboard the NASA DC-8. The results indicate that scattering measurements for ammonium sulfate and sea salt (from a filtered North Pacific subtropical gyre seawater standard; Karl and Lukas, 1996) are within 25\% of the values calculated from size distributions considering salt densities and optical properties at $80 \%$ relative humidity (Tang, 1997; Tang and Munkelwitz, 1994; Tang et al., 1997). Since $\mathrm{f}(\mathrm{RH})$ is computed from a two point fit of the ratio between the dry and wet scattering values the $\mathrm{f}(\mathrm{RH})$ measurement could be low by up to a factor of 0.7 or overestimated by up to a factor of 1.3 .

\subsection{Fitting aerosol size distributions using lognormal distributions}

In this analysis, DMA, OPC and APS size distributions are averaged, combined, then fit using log-normal distributions (Baron and Willeke, 2001; Seinfeld and Pandis, 1998). The largest disparity occurs between the OPC and the LDMA over the $0.30-0.50 \mu \mathrm{m}$ size range. OPC number agreement is $71 \%\left(R^{2}=0.922\right)$ and volume agreement is $60 \%\left(R^{2}=0.910\right)$ due to the large OPC Mie oscillation over this size range. The overall agreement for the OPC and LDMA between 0.12 and $0.50 \mu \mathrm{m}$ is $92 \%\left(R^{2}=0.918\right)$ for aerosol number, and $85 \%\left(R^{2}=0.966\right)$ for aerosol volume. Other researchers have applied log-normal fitting routines using least squares optimization (Hand and Kreidenweis, 2002; Osborne and Haywood, 2005; Porter and Clarke, 1997). However, in the cases cited only one moment of the aerosol size distribution is considered during the fit. When fitting the number distribution (Osborne and Haywood, 2005; Porter and Clarke, 1997) the tail of the distribution does not significantly contribute to the least squares error. But, the tail of the number distribution contains all of the aerosol volume and will be poorly constrained by fitting the distribution using only aerosol number. Similarly, when fitting using the volume distribution (Hand and Kreidenweis, 2002) aerosol number will be poorly fit.

To avoid the problems associated with fitting a single mode of the distribution, we (S. Howell) developed a least squares fitting routine which simultaneously evaluates the least squares error for the number, length, area and volume distributions (i.e. the zeroth through third moments). This technique is similar to that of Stroud et al. (2007), who simultaneously fit the number and volume distribution from an SMPS and the mass distributions from an aerosol mass spectrometer. Using multiple moments results in better fits, which do not bias the results by large errors contributed from a single mode. Typically, one to three modes (termed the 
Aitken, accumulation and coarse modes), were required to fit the unheated distributions. In general only two fits, Aikten and coarse mode, are required to fit the refractory aerosol distributions. As indicated in our previous studies (Clarke et al., 2004, 2007), the refractory Aitken mode aerosol is found to be an internally mixed component of some fraction of the unheated accumulation mode aerosol.

\subsection{Aerosol chemistry measurements}

Aboard the NASA DC-8 the University of New Hampshire collects total aerosol filters with 300-600 second resolution, measuring $\mathrm{Na}^{+}, \mathrm{NH}_{4}^{+}, \mathrm{K}^{+}, \mathrm{Mg}^{2+}, \mathrm{Ca}^{2+}, \mathrm{Cl}^{-}, \mathrm{NO}_{3}^{-}$, $\mathrm{SO}_{4}^{2-}$, and $\mathrm{C}_{2} \mathrm{O}_{4}^{2-}$ using ion chromatography (Dibb et al., 2003b). Measurements of ${ }^{7} \mathrm{Be}$ are performed using gammaspectroscopy (Dibb et al., 1997). Fast (90-second) measurements of $\mathrm{HNO}_{3}(\mathrm{~g})$ and submicrometer $\mathrm{SO}_{4}^{2-}$ are measured using ion-chromotography coupled to a mist chamber (Scheuer et al., 2003). Aboard the NSF/NCAR C130, the University of Colorado measured submicrometer non-refractory aerosol chemistry $\left(\mathrm{NH}_{4}^{+}, \mathrm{NO}_{3}^{-}, \mathrm{SO}_{4}^{2-}, \mathrm{NR}\right.$ $\mathrm{Cl}^{-}$, and organics) using a high-resolution time-of-flight aerosol mass spectrometer (HR-ToF-AMS) (Canagaratna et al., 2007; DeCarlo et al., 2006, 2008; Dunlea, 2009). The HR-ToF-AMS data are recorded as $10 \mathrm{~s}$ averages and further averaged into 60 -s samples.

\subsection{Trace gas measurements}

DC-8 trace gas measurements of $\mathrm{NO}_{2}, \mathrm{HNO}_{3}$, total peroxynitrates (PNs), alkyl- and hydroxyalkyl nitrates (ANs) were measured by the University of California, Berkeley using thermal-dissociation coupled to laser-induced fluorescence (TD-LIF) (Day et al., 2002; Thornton et al., 2000). Based on previous studies (Miyazaki et al., 2005; Zondlo et al., 2003) and recent measurements during ARCTAS (P. Wennberg, personal communication, 2009), it is likely that the UC Berkeley TD-LIF and UNH DC-8 mist chamber measurements of $\mathrm{HNO}_{3}$ include a 10-30\% enhancement due to contamination by $\mathrm{NH}_{4} \mathrm{NO}_{3}$ aerosol. Larger enhancements are possible in the presence of dust (Miyazaki et al., 2005). For INTEX-B the two $\mathrm{HNO}_{3}$ measurements are highly correlated over more than 2 orders of magnitude $\left(\mathrm{m}=0.89, R^{2}=0.83\right.$ ) and are averaged to produce a single measure of $\mathrm{HNO}_{3}$. No attempt has been made to correct the $\mathrm{HNO}_{3}$ data for particulate nitrate contamination. $\mathrm{SO}_{2}$ was measured by the Georgia Institute of Technology chemical ionization mass spectrometer (Kim et al., 2007). NO was measured using chemiluminescence (Sjostedt et al., 2007). $\mathrm{HCl}$ was measured by the Georgia Institute of Technology using a chemical ionization mass spectrometer (Kim et al., 2008 and refs). Ozone was measured using nitric oxide chemiluminescence by the NASA Langley Research Center (Davis et al., 2003).

Aboard the NSF/NCAR C-130, $\mathrm{HNO}_{3}$ was measured by the California Institute of Technology using a chemical ion- ization mass spectrometer (Crounse et al., 2006). NO, $\mathrm{NO}_{2}, \mathrm{NO}_{\mathrm{y}}$, and $\mathrm{O}_{3}$ were measured by a team from the $\mathrm{Na}$ tional Center for Atmospheric Research (NCAR) using a 1$\mathrm{Hz}$ chemiluminescence technique (Weinheimer et al., 1998). PAN was measured by an NCAR team using thermal decomposition chemical ionization spectrometry (Slusher et al., 2004).

\section{Results}

\subsection{Anthropogenic pollution and Asian Dust over the Eastern North Pacific}

DC-8 data from the Pacific Phase of INTEX-B is stratified into data collected near Hawaii (Latitude $<40^{\circ} \mathrm{N}$ ) and Alaska (Latitude $>40^{\circ} \mathrm{N}$ ). The locations correspond to the climatological features known as the East Pacific High and the Aleutian Low. Sampling was conducted between April $15^{\text {th }}$ and May $1^{s t}, 2006$ near Hawaii and between May $1^{s t}$ and $15^{\text {th }}$, near Alaska. The free troposphere (GPS altitudes $>1.5 \mathrm{~km}$ ) during this time was widely influenced by Asian pollution as well as Asian dust (Dunlea, 2009; Singh et al., 2009). After excluding clean FT airmasses $(\mathrm{CO}<90 \mathrm{ppbv}$; $\mathrm{O}_{3}<40 \mathrm{ppbv}$ ), and those indicative of stratospheric influence $\left({ }^{7} \mathrm{Be}>800 \mathrm{fCi} \mathrm{sm}^{-3}\right.$, where $\mathrm{sm}^{-3}$ denotes concentrations per cubic meter of air at $1013.25 \mathrm{mb}$ and $273.15 \mathrm{~K}$ ), the data were further stratified using the fine mode fraction of aerosol light scattering (Anderson et al., 2003).

$\boldsymbol{F} M F_{\mathrm{scat}}=\frac{\sigma_{\mathrm{sp}, 550, \mathrm{Dae}<1.0}}{\sigma_{\mathrm{sp}, 550}}$

When $\mathrm{FMF}_{\text {scat }}>0.6$, and scattering exceeded $3 \mathrm{Mm}^{-1}$, the airmasses are considered "fine" mode dominated anthropogenic pollution. Values of $0.3<\mathrm{FMF}_{\text {scat }}<0.6$ are labeled "mixed" pollution and mineral dust. No data met the "dusty" $\mathrm{FMF}_{\text {scat }}<0.3$ criteria of Anderson et al. (2003).

Lognormal fits of the anthropogenic and mixed aerosol size distributions measured near Hawaii are presented in Fig. 1. The top two panels are the number and volume distributions for the fine mode dominated case whereas the bottom panels are for the mixed airmass type. Differences between the unheated and refractory fits to the supermicrometer dust mode are not significant and the summary statistics in Table 2 are pooled into a single supermicrometer aerosol fit. Figure 2 assesses the degree of aerosol number closure by comparing the integrals of the lognormal fits to the average concentrations measured using the hot and cold $\mathrm{CN}$ counters ( $\mathrm{N}$ for $\mathrm{Dp}>10 \mathrm{~nm}$ sampled at 1-Hz). Size distribution integrals reasonably replicate the faster $\mathrm{CN}$ counter averages and support the use of these fits to constrain model simulations of the aerosol size distribution. Figures 3 and 4 are the fits and the number closure assessment for the data collected in the FT of the Aleutian Low. For these cases refractory number 
Table 2. Summary of log-normal fitting results for free troposphere pollution and pollution mixed with dust airmasses sampled over the Eastern North Pacific during INTEX-B.

\begin{tabular}{|c|c|c|c|c|c|c|}
\hline \multirow{2}{*}{ Region } & \multirow{2}{*}{ Aerosol Type } & \multicolumn{5}{|c|}{ Accumulation Mode } \\
\hline & & $\mathrm{N}\left(\# \mathrm{~cm}^{-3}\right)$ & $\mathrm{NMD}(\mu \mathrm{m})$ & $\mathrm{V}\left(\mu \mathrm{m}^{3} \mathrm{~cm}^{-3}\right)$ & $\mathrm{VMD}(\mu \mathrm{m})$ & sigma_g (-) \\
\hline \multirow{2}{*}{ HI } & Mixed & 430 & 0.075 & 0.75 & 0.30 & 1.97 \\
\hline & Anthro & 387 & 0.093 & 0.75 & 0.26 & 1.79 \\
\hline \multirow{2}{*}{$\mathrm{AK}$} & Mixed & 433 & 0.074 & 0.73 & 0.30 & 1.98 \\
\hline & Anthro & 423 & 0.11 & 1.3 & 0.27 & 1.70 \\
\hline \multirow{2}{*}{ Region } & \multirow{2}{*}{ Aerosol Type } & \multicolumn{5}{|c|}{ Coarse Mode } \\
\hline & & $\mathrm{N}\left(\# \mathrm{~cm}^{-3}\right)$ & $\mathrm{NMD}(\mu \mathrm{m})$ & $\mathrm{V}\left(\mu \mathrm{m}^{3} \mathrm{~cm}^{-3}\right)$ & $\operatorname{VMD}(\mu \mathrm{m})$ & sigma_g (-) \\
\hline \multirow{2}{*}{ HI } & Mixed & 5.3 & 0.64 & 7.4 & 3.1 & 2.06 \\
\hline & Anthro & 3.5 & 0.56 & 2.6 & 2.5 & 2.03 \\
\hline \multirow{2}{*}{ AK } & Mixed & 7.9 & 0.50 & 6.8 & 2.8 & 2.13 \\
\hline & Anthro & 1.4 & 0.75 & 1.8 & 2.6 & 1.91 \\
\hline \multirow{2}{*}{ Region } & \multirow{2}{*}{ Aerosol Type } & \multicolumn{5}{|c|}{ Refractory Aitken Mode } \\
\hline & & $\mathrm{N}\left(\# \mathrm{~cm}^{-3}\right)$ & $\operatorname{NMD}(\mu \mathrm{m})$ & $\mathrm{V}\left(\mu \mathrm{m}^{3} \mathrm{~cm}^{-3}\right)$ & $\operatorname{VMD}(\mu \mathrm{m})$ & sigma_g $(-)$ \\
\hline \multirow{2}{*}{ HI } & Mixed & 290 & 0.036 & 0.07 & 0.17 & 2.05 \\
\hline & Anthro & 300 & 0.044 & 0.10 & 0.16 & 1.94 \\
\hline \multirow{2}{*}{ AK } & Mixed & 300 & 0.044 & 0.06 & 0.12 & 1.79 \\
\hline & Anthro & 350 & 0.053 & 0.17 & 0.18 & 1.88 \\
\hline
\end{tabular}
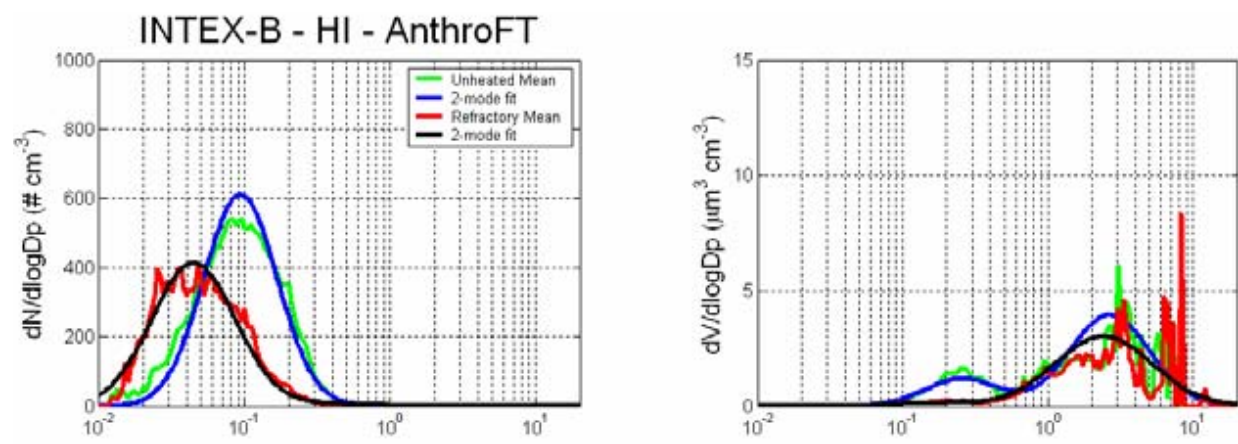

INTEX-B - HI - MixedFT
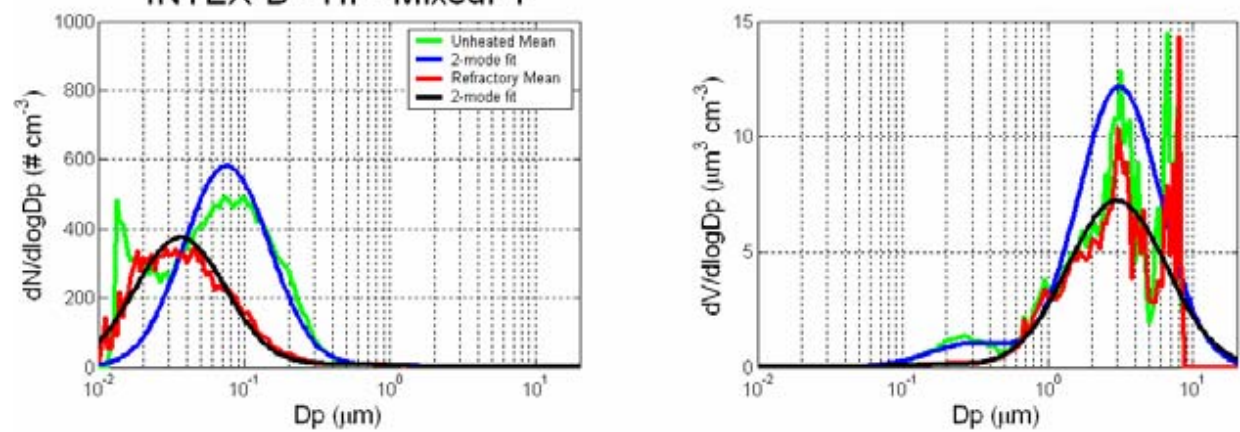

Fig. 1. Lognormal fits of the number (left) and volume (right) aerosol size distributions measured in the FT near Hawaii during INTEX-B. Total aerosol and the 2-mode fit are in green and blue while refractory aerosol is coloured red and black. 

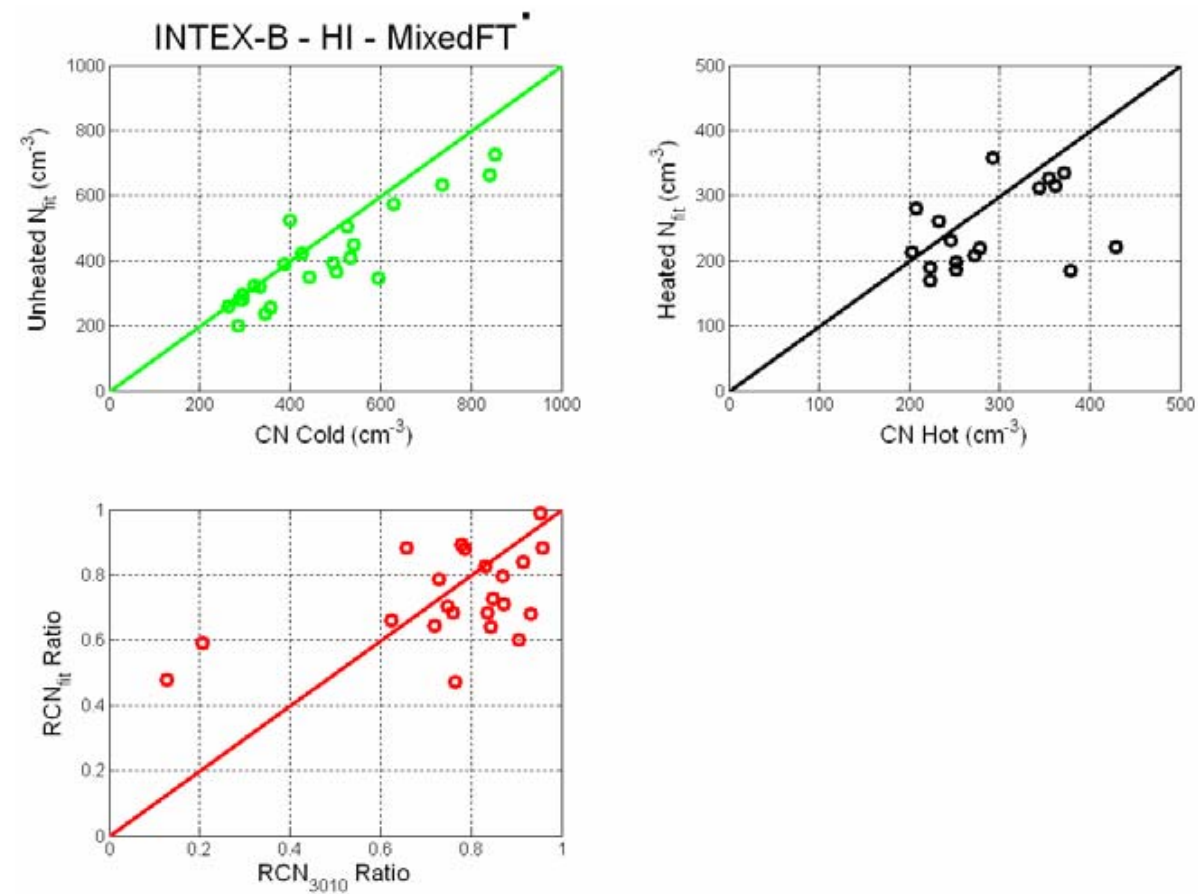

Fig. 2. Assessment of number closure between the lognormal fits to the unheated and refractory aerosol distribution and to their ratio (RCN ratio) compared to the averaged $1-\mathrm{Hz} \mathrm{CN}$ counter data.
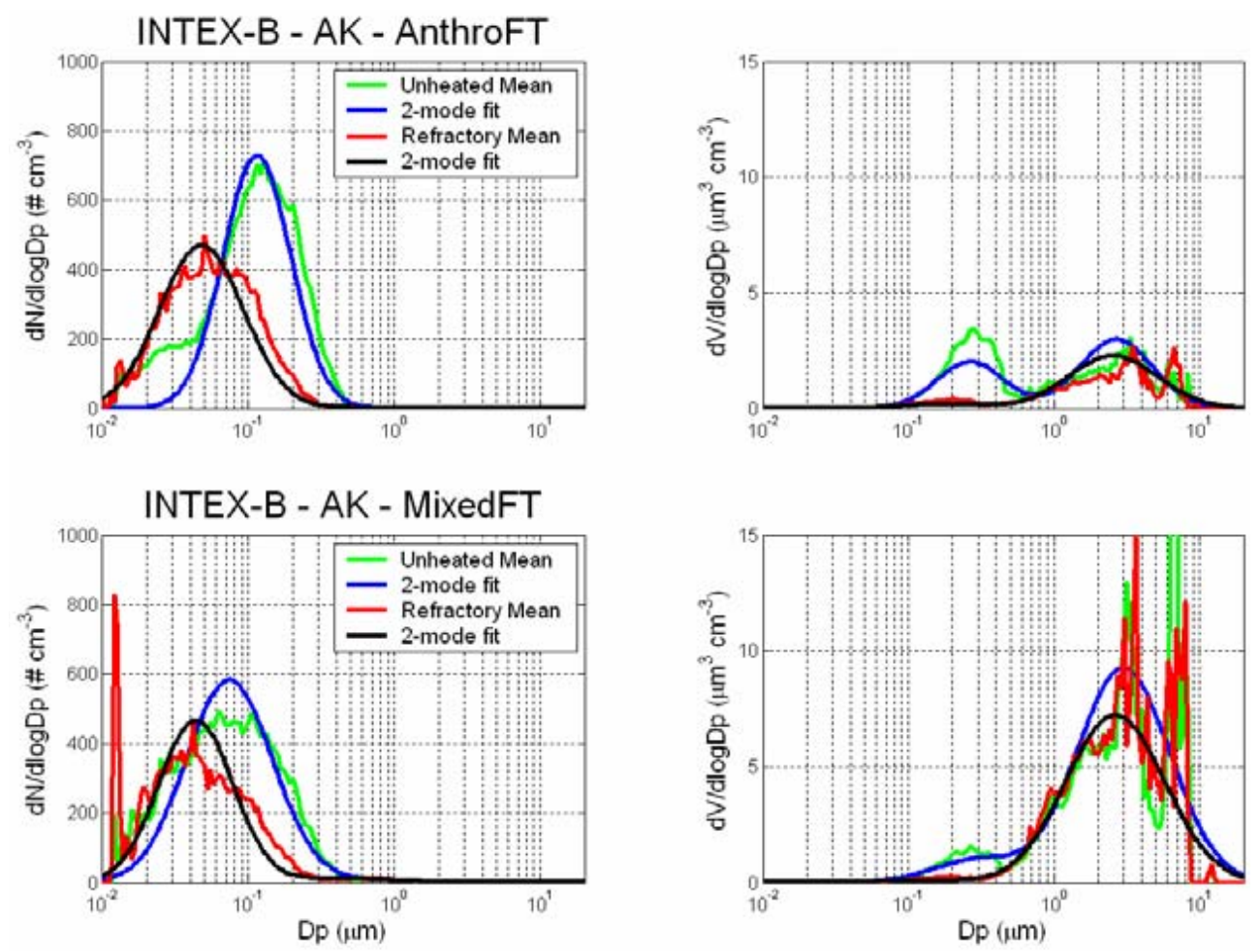

Fig. 3. Same as Fig. 1 but for data collected in the FT near Alaska. 

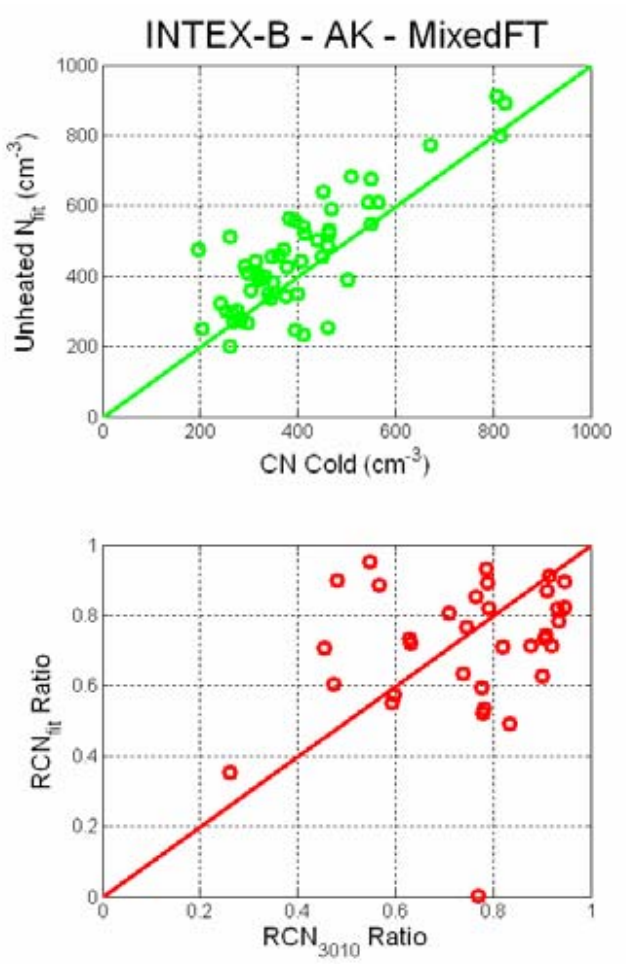

Fig. 4. Same as Fig. 2 but for data collected in the FT near Alaska.

is somewhat higher in the fit data resulting in fair agreement between the RCN ratios.

Table 2 summarizes the mean log-normal fits to the accumulation mode, coarse mode and refractory Aitken mode size distributions measured near Hawaii and Alaska for the fine mode dominated and mixed airmass types. After long range transport, the number median diameter (NMD) of FT Asian pollution $\left(\mathrm{FMF}_{\text {scat }}>0.6\right)$ aerosol varies $(+/-1-\sigma)$ between 0.086 and $0.15 \mu \mathrm{m}$ with an average value of $0.11 \mu \mathrm{m}$ and a geometric standard deviation, $\sigma_{g}$, of $1.70+/-0.15$. The observed range $(+/-1-\sigma)$ of volume median diameters (VMD) is between 0.24 and $0.30 \mu \mathrm{m}$. In the presence of dust $\left(0.3<\mathrm{FMF}_{\text {scat }}<0.6\right)$, the NMD of FT Asian aerosol varies between $0.051-0.11 \mu \mathrm{m}$ with a smaller average NMD of $0.075 \mu \mathrm{m}$. In the presence of dust the accumulation mode aerosol has a broader distribution, $\sigma_{g}=1.97+/-0.20$, which results in a range of VMD's between 0.26 and $0.35 \mu \mathrm{m}$. Despite their larger VMD's, for a fixed number of particles, the average value of the fit to the "mixed" aerosol types result in 30\% less aerosol volume than under low-dust conditions. This is close to the significant difference $(\alpha=0.05)$ of $40 \%$ between the average accumulation mode volumes for the observed distributions $\left(\mathrm{V}_{\text {anthro }}=1.4+/-1.5 \mu \mathrm{m}^{3} \mathrm{~cm}^{-3}\right.$; $\left.\mathrm{V}_{\text {dusty }}=0.86+/-0.64 \mu \mathrm{m}^{3} \mathrm{~cm}^{-3}\right)$; a quantity that will vary due to factors such as emissions source strength, transport pathway etc.

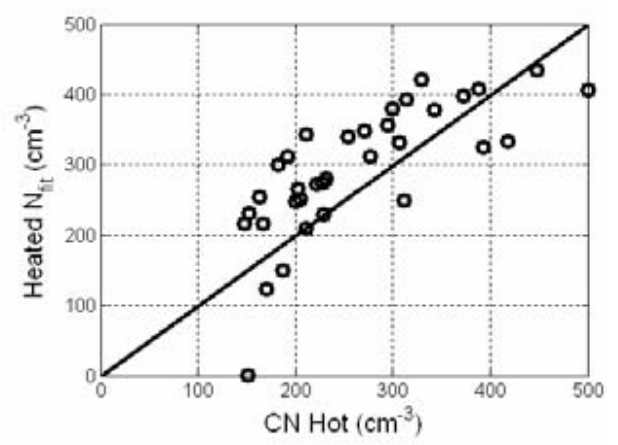

The total and refractory number distributions highlight the internally mixed nature of the refractory soot particulate coated with the non-refractory compounds, $\mathrm{NH}_{4}^{+}, \mathrm{SO}_{4}^{2-}$, $\mathrm{NO}_{3}^{-}$and organics. The ratio of refractory number to total number in these airmasses averages 0.75 indicating only $25 \%$ of the pollution aerosol is composed of externally mixed secondary aerosol number. The refractory aerosol NMD's for Hawaii and Alaska vary between 0.032 and $0.066 \mu \mathrm{m}$ with a mean value of $0.046 \mu \mathrm{m}$. The geometric standard deviation is variable but averages $1.91+/-0.23$. This results in a range of VMD's between 0.10 and $0.26 \mu \mathrm{m}$ for the refractory material. The average refractory volume ratio of the log normal fits is $14-19 \%$, in good agreement with the observed average refractory volume ratios of $12-16 \%+/-7 \%$. The INTEX-B observations of reductions in accumulation mode secondary aerosol mass due to competition by dust surface area is consistent with previous observations near the Asian source region (Howell et al., 2006). Models which attempt to simulate these aerosol should account for this internal mixing as surface coatings of non-absorbing secondary aerosol on internally mixed carbonaceous primary aerosol will affect aerosol optical properties (Clarke et al., 2004; Fuller et al., 1999; Schnaiter et al., 2005).

Total aerosol single scatter albedo (SSA) at $550 \mathrm{~nm}$ measured $0.94+/-0.03$ and $0.95+/-0.01$ for fine mode dominated $\left(\mathrm{FMF}_{\text {scat }}>0.6\right)$ airmasses sampled near Hawaii and Alaska. Using a one-tailed Student's t-test these values are 
Table 3. Summary of total single scatter albedo, scattering and absorption Ångstrom exponents for 300-s level leg averages during INTEX-B. "Anthro" are fine mode dominated aerosol (FMFscat $>0.6)$ while "Mixed" aerosols are for mixtures of pollution and dust $(0.3<$ FMFscat $<0.6)$. The standard deviations of the means are shown in brackets.

\begin{tabular}{|c|c|c|c|c|c|c|c|c|}
\hline \multicolumn{2}{|c|}{ Hawaii } & $\mathrm{N}$ & \multicolumn{3}{|c|}{ Total SSA } & \multicolumn{3}{|c|}{ Total Ångstrom Exponent } \\
\hline LT & $\begin{array}{l}\text { Mixed } \\
\text { Anthro }\end{array}$ & $\begin{array}{l}15 \\
10\end{array}$ & $\begin{array}{l}450 \mathrm{~nm} \\
0.95(0.02) \\
0.93(0.03)\end{array}$ & $\begin{array}{l}550 \mathrm{~nm} \\
0.96(0.02) \\
0.94(0.03)\end{array}$ & $\begin{array}{l}700 \mathrm{~nm} \\
0.97(0.02) \\
0.94(0.03)\end{array}$ & $\begin{array}{l}\text { Scat }(450 / 700) \\
0.54(0.22) \\
1.06(0.34)\end{array}$ & $\begin{array}{l}\text { Abs }(470 / 660) \text { Bond Correction } \\
2.8(1.1) \\
2.2(0.6)\end{array}$ & $\begin{array}{l}\text { Abs }(470 / 660) \text { Virkkula Correction } \\
2.6(0.9) \\
2.0(0.6)\end{array}$ \\
\hline \multicolumn{2}{|c|}{ Alaska } & $\mathrm{N}$ & \multicolumn{3}{|c|}{ Total SSA } & \multicolumn{3}{|c|}{ Total Ångstrom Exponent } \\
\hline LT & $\begin{array}{l}\text { Mixed } \\
\text { Anthro }\end{array}$ & $\begin{array}{l}14 \\
40\end{array}$ & $\begin{array}{l}450 \mathrm{~nm} \\
0.96(0.02) \\
0.94(0.01)\end{array}$ & $\begin{array}{l}550 \mathrm{~nm} \\
0.97(0.02) \\
0.95(0.01)\end{array}$ & $\begin{array}{l}700 \mathrm{~nm} \\
0.97(0.02) \\
0.94(0.02)\end{array}$ & $\begin{array}{l}\text { Scat }(450 / 700) \\
0.64(0.38) \\
1.53(0.37)\end{array}$ & $\begin{array}{l}\text { Abs }(470 / 660) \text { Bond Correction } \\
2.7(1.5) \\
1.8(0.4)\end{array}$ & $\begin{array}{l}\text { Abs (470/660) Virkkula Correction } \\
2.5(1.4) \\
1.7(0.4)\end{array}$ \\
\hline \multicolumn{2}{|c|}{ Mexico } & $\mathrm{N}$ & \multicolumn{3}{|c|}{ Total SSA } & \multicolumn{3}{|c|}{ Total Ångstrom Exponent } \\
\hline $\begin{array}{l}\text { LT } \\
\text { CBL } \\
\text { MBL }\end{array}$ & Anthro & $\begin{array}{l}52 \\
24 \\
56\end{array}$ & $\begin{array}{l}450 \mathrm{~nm} \\
0.94(0.01) \\
0.93(0.01) \\
0.96(0.02)\end{array}$ & $\begin{array}{l}550 \mathrm{~nm} \\
0.94(0.01) \\
0.93(0.01) \\
0.96(0.02)\end{array}$ & $\begin{array}{l}700 \mathrm{~nm} \\
0.94(0.01) \\
0.93(0.02) \\
0.96(0.02)\end{array}$ & $\begin{array}{l}\text { Scat }(450 / 700) \\
1.52(0.30) \\
1.50(0.42) \\
1.33(0.38)\end{array}$ & $\begin{array}{l}\text { Abs }(470 / 660) \text { Bond Correction } \\
2.2(0.3) \\
2.1(0.6) \\
2.0(0.9)\end{array}$ & $\begin{array}{l}\text { Abs }(470 / 660) \text { Virkkula Correction } \\
2.0(0.3) \\
1.9(0.5) \\
1.8(0.7)\end{array}$ \\
\hline
\end{tabular}

significantly higher than the value of $0.90+/-0.02$ measured near the East Asian source region during ACE-Asia (Anderson et al., 2003). The INTEX-B and ACE-Asia measurements use the same instrumentation with comparable levels of uncertainty. The only difference is the use of the Virkkula et al. (2005) PSAP correction for INTEX-B rather than the Bond et al. (1999) correction for ACE-Asia. The correction factor does not significantly alter the means indicating an increase in SSA during long-range transport of Asian pollution across the Pacific. The $550 \mathrm{~nm}$ SSA's for mixed airmasses $\left(0.3<\mathrm{FMF}_{\text {scat }}<0.6\right)$ measured near Hawaii and Alaska have values of 0.96 and $0.97(+/-0.02)$, significantly different than the $0.91(+/-0.02)$ measured near East Asia. The SSA's at 450 and $700 \mathrm{~nm}$ are included in Table 3 along with the values measured in the continental boundary layer over the Central Mexican Plateau and the FT and MBL over the Gulf of Mexico.

Measurements of 3- $\lambda$ total aerosol scattering and absorption allow us to investigate the wavelength dependence of extinction for Asian aerosol after long-range transport to the remote North Pacific. Table 3 summarizes the total scattering Ångstrom exponent as well as the total absorption Ångstrom exponents measured for the fine mode dominated and mixed aerosols. The averages are computed from 5-min level leg FT averages where the measured absorption is above $0.1 \mathrm{Mm}^{-1}$. Values from the Central Mexican Plateau and the FT over the Gulf of Mexico are also included for comparison. The Hawaii data show the lowest scattering Ångstrom exponents and the highest absorption Ångstrom exponents while the data from the CBL near Mexico City have the lowest singlescatter albedo's.

Submicrometer absorption Ångstrom exponents are always higher when dust is present (not shown). The $\mathrm{f}(\mathrm{RH})$ measurements (Table 4) also show that submicrometer $\mathrm{f}(\mathrm{RH})$ $\gamma$ is suppressed $(0.39-0.44)$ in the presence of dust when
Table 4. Summary of total and submicrometer $\mathrm{f}(\mathrm{RH})$ "gamma" for $300 \mathrm{~s}$ level leg averages during INTEX-B. "Fine" mode dominated aerosol are defined as (FMFscat $>0.6$ ) while "mixed" aerosol are for mixtures of pollution and dust where $(0.3<$ FMFscat $<0.6)$. The standard deviations of the means are shown in brackets.

\begin{tabular}{llllll}
\hline & Hawaii & \multicolumn{2}{c}{ Submicrometer } & \multicolumn{2}{c}{ Total Aerosol } \\
\hline & & $\mathrm{N}$ & gamma & $\mathrm{N}$ & gamma \\
\hline LT & Mixed & 9 & $0.39(0.07)$ & 2 & 0.34 \\
& Anthro & 7 & $0.44(0.14)$ & 2 & 0.52 \\
\hline & Alaska & \multicolumn{2}{c}{ Submicrometer } & \multicolumn{2}{c}{ Total Aerosol } \\
\hline \multirow{2}{*}{ UT } & STE - median & 5 & $0.55(0.15)$ & & \\
LT & Mixed & 8 & $0.32(0.11)$ & 4 & $0.29(0.11)$ \\
& Anthro & 34 & $0.44(0.12)$ & 5 & $0.50(0.07)$ \\
\hline \multirow{2}{*}{ Mexico } & Submicrometer & Total Aerosol \\
\hline \multirow{2}{*}{ LT } & Anthro & gamma & N & gamma \\
CBL & Anthro & 9 & $0.39(0.06)$ & 3 & $0.32(0.09)$ \\
MBL & Anthro & 22 & $0.63(0.06)$ & 7 & $0.65(0.04)$ \\
\hline
\end{tabular}

compared to fine-mode dominated values of $\gamma(0.44-0.50)$. These two measurements indicate that a portion of the dust is passing the $1.0 \mu \mathrm{m}$ aerodynamic (at STP) cut-off of the impactor plate. Ignoring shape factor, the impactor's $50 \%$ cut corresponds to a geometric diameter of $0.67 \mu \mathrm{m}$ for a mineral dust aerosol with a density of $2.06 \mathrm{~g} \mathrm{~cm}^{-3}$. Based on the $\log$ normal fit for the Hawaii mixed aerosol data $\left(\mathrm{N}=5.3 \mathrm{~cm}^{-3}\right.$, $\mathrm{NMD}=0.64 \mu \mathrm{m}, \sigma_{g}=2.06$ ), this "submicrometer" dust is $0.3 \mu \mathrm{g} \mathrm{m}^{-3}$ of the total, $15.7 \mu \mathrm{g} \mathrm{m}^{-3}$. Using a refractive index of 1.53-0.0006i, the "submicrometer" tail of the dust distribution, which accounts for just $2 \%$ of the dust mass, accounts for $11 \%$ of the extinction by mineral dust. 

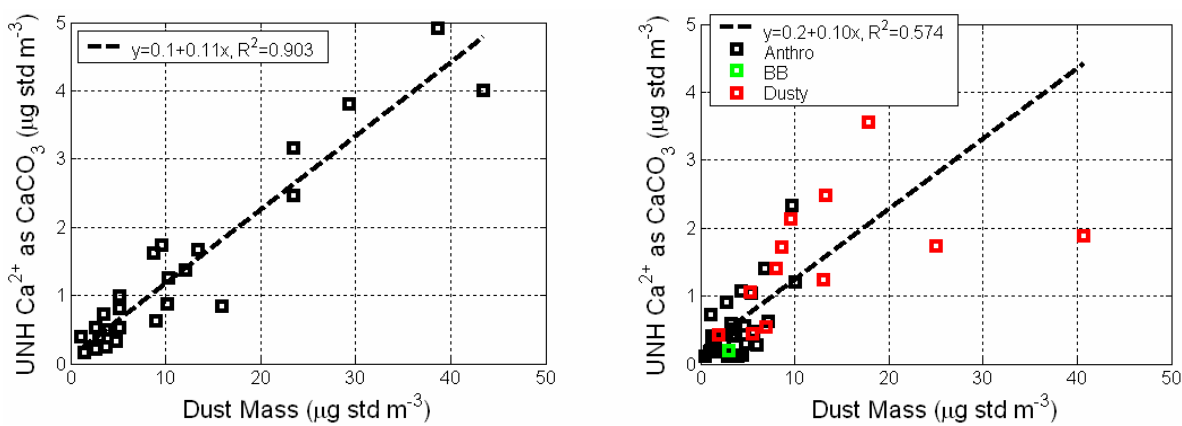

Fig. 5. Regressions of $\mathrm{UNH} \mathrm{Ca}^{2+}$ as $\mathrm{CaCO}_{3}$ versus size distribution integral mass (assumes density of $2.06 \mathrm{~g} \mathrm{~cm}^{-3}$ ) for Hawaii (left) and Alaska (right). Regressions indicate an $11 \mathrm{wt} \%$ estimate for the mineral dust calcite content.

Poorly modeling the lower tail of the mineral aerosol size distribution ( $2 \%$ of dust mass) can result in larger errors in aerosol extinction $(11 \%$ of dust extinction at $550 \mathrm{~nm})$. As shown by the wavelength dependence measurements, this error will compound when calculating extinction at shorter visible wavelengths and in the UV (Sokolik and Toon, 1999) as well as for dusts with differing composition (e.g. Lafon et al., 2006). Thus accurately modeling the direct and indirect effects of mineral dust likely requires dynamic aerosol size distributions with size resolved, and source-dependent, mineral composition.

\subsection{Heterogeneous chemistry of Asian Dust over the Eastern North Pacific}

The previous section demonstrated that Asian pollution and dust commonly occur together in polluted airmasses transported long-range across the Pacific. In this subsection we examine the chemistry of accumulation mode and coarse mode aerosol measured in the pollution/dust plumes over the Eastern North Pacific. University of New Hampshire filterbased measurements of $\mathrm{Ca}^{2+}$ can be converted into calcite $\left(\mathrm{CaCO}_{3}\right)$ mass assuming that the weak-acid eluent of the UNH ion chromatography analysis does not measure the aluminosilicate's structural calcium. When these values are regressed against the HiGEAR data (Fig. 5) we estimate a calcite content of $11 \mathrm{wt} \%$ for the Hawaii region $\left(R^{2}=0.90\right)$ and $10 \mathrm{wt} \%\left(R^{2}=0.57\right)$ for the Alaska region. The low $R^{2}$ of the Alaskan fit is being driven by the two highest values of aerosol $\mathrm{Ca}^{2+}$. A calcite weight percent of $10-11 \%$ is in good agreement with soil carbonate values reported by Liu (1985) (3.6-21\%; mean value of $12 \%)$, and $14-17 \%\left(\mathrm{~d}_{m}<40.0 \mu \mathrm{m}\right)$ reported by Wang et al. (2005). The $10-11 \%$ derived here for aerosol carbonate is also relatively consistent with values reported for clay grade $\left(\mathrm{d}_{m}<6.0 \mu \mathrm{m} ; 6.5+/-6.2 \%\right)$ Asian particulate (Liu, 1985), measurements of 5-8 wt\% soluble aerosol calcium during ACE-Asia (Kline et al., 2004) and $8.2+/-3.2 \mathrm{wt} \%$ measured in aerosol collected by Wang et al. (2005). As per Wang et al. (2005), the high calcite content measured during INTEX-B is indicative of a Western Chinese source provenance for this material.
The ratio of sulfate aerosol to the sum of gas phase $\mathrm{SO}_{2}$ plus sulfate aerosol (S-ratio) has been shown to increase with airmass age (Brock et al., 2008; Dunlea, 2009). Values greater than $\sim 0.5$ generally indicate airmass ages greater than $\sim 3$ days, although lower values can be observed in older airmasses after wet deposition. In the presence of the dust we can expect heterogeneous reactions to drive the S-ratio toward unity at a faster rate. Jordan et al. (2003a) evaluated the ratio of particulate nitrate $\left(\mathrm{NO}_{3}^{-}\right)$to nitrate plus nitric acid (N-ratio) in order to evaluate the heterogeneous uptake of $\mathrm{NO}_{\mathrm{x}}$ species by alkaline dust. Their observations show that in the presence of dust, particulate nitrate accounts for $50-60 \%$ of total nitrate. The values range between $25 \%$ and $50 \%$ without dust. Using single particle analysis Sullivan et al. (2007a), found that Fe-rich Asian dust particles were closely associated with secondary sulfate whereas $\mathrm{Ca}$ rich particulate could contain secondary sulfate, nitrate and chloride. Reaction between aerosol carbonate and $\mathrm{HCl}$ derived from the acidification of seasalt by $\mathrm{SO}_{\mathrm{x}}$ or $\mathrm{NO}_{\mathrm{x}}$ has also recently been observed (Murphy et al., 2006; Sullivan et al., 2007b).

Figure 6 plots the S-ratio, N-ratio, a modified N-ratio, and the ratio of aerosol chloride to $\mathrm{HCl}$ plus chloride (Cl-ratio) versus calcium as measured between Hawaii and Alaska during INTEX-B. The plots are color coded by scattering Ångstrom exponent. High values (red = 3.0) are indicative of small particles found in pollution dominated airmasses. Low values (blue $=-0.5$ ) are indicative of airmasses whose optical properties are dominated by supermicrometer dust. For the S-ratio (far-left) there is no clear dependence with calcium concentration. This indicates that airmass age and/or scavenging could control the partitioning of sulfur. The $\mathrm{N}$ ratio versus $\mathrm{Ca}^{2+}$ plot (center-left) shows that for low $\mathrm{Ca}^{2+}$ concentrations $(<20$ neq sm-3) the ratio averages $47 \%(+/-$ $22 \%$ ) and that at higher concentrations ( $>20$ neq sm-3) the value averages $65 \%(+/-25 \%)$, a significant difference using a two-tailed Student's t-test $(\alpha=0.05)$. The effect of these reactions is even more striking when aerosol nitrate is divided by the sum of all nitrogen species $\left(\mathrm{NO}, \mathrm{NO}_{2}\right.$, $\mathrm{HNO}_{3}, \mathrm{PAN}, \mathrm{ANs}, \mathrm{PNs}$, and $\mathrm{NO}_{3}^{-}$). The presence of dust 


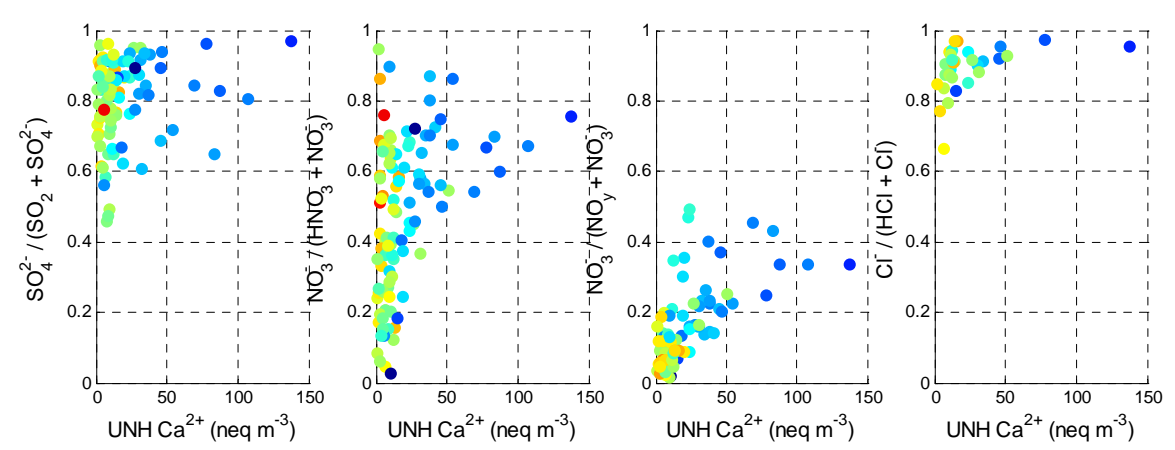

Fig. 6. Ratio of aerosol sulfur to total sulfur (far left), aerosol nitrate to nitrate plus nitric acid gas (center-left), aerosol nitrate to the sum of nitrogen species (center-right) and aerosol chloride to sum of hydrogen chloride gas and aerosol chloride (far-right). Data are color coded by scattering ngstrom exponents; large values (red) indicate pollution dominated airmasses, while small or negative values (blue) indicate the presence of dust.

is clearly sequestering gas-phase nitrogen species into the particulate-phase (Fig. 6, center-right). Aerosol nitrate accounts for only $10 \%(+/-6 \%)$ of the nitrate in the low dust group $\left(<20\right.$ neq sm-3 $\left.\mathrm{Ca}^{2+}\right)$ whereas it averages $26 \%$ $(+/-11 \%)$ in the high dust group and has maximum values approaching 50\%. A similar trend is evident for the uptake of $\mathrm{Cl}^{-}$by dust. We find that $88 \%(+/-7.5 \%)$ of the chloride is associated with particulate for low dust concentrations $\left(\mathrm{Ca}^{2+}<20\right.$ neq sm-3) compared to $92 \%(+/-3.6 \%)$ for high dust concentrations; values which are significantly different $(\alpha=0.05, p=0.02)$.

These reactions are explored further in Fig. 7. The top row plots aerosol $\mathrm{SO}_{4}^{2-}, \mathrm{NO}_{3}^{-}$and $\mathrm{Cl}^{-}$in neq sm${ }^{-3}(\mathrm{~T}=273.15$ $\mathrm{K}, \mathrm{P}=101.325 \mathrm{kPa}$ ) versus the equivalents of $\mathrm{Ca}^{2+}$. The regression for total sulfate is poor and does not improve after subtracting the submicrometer sulfate. And although Chinese Loess is not rich in $\mathrm{CaSO}_{4}$ (Liu, 1985), Arimoto et al. (2004) reported an $\mathrm{SO}_{4}^{2-}$ to $\mathrm{WS} \mathrm{Ca}^{2+}$ molar ratio of $0.09+/-0.04$ for clean, dust dominated $\left(>40 \mu \mathrm{g} \mathrm{m}^{-3}\right)$ aerosols at Zhenbeitai, China during ACE-Asia. A ratio of 0.1 is also the minimum value measured by Kline et al. (2004) aboard the NSF/NCAR C-130 during ACE-Asia. The poor fit $\left(R^{2} \sim=0.20\right)$ and slope of 0.15 for supermicrometer only aerosol means we cannot rule out the possible presence of gypsum. The regression for nitrate indicates a close coupling between the presence of aerosol nitrate and mineral dust $\left(\mathrm{m}=0.14, R^{2}=0.69\right.$ ). Primary $\mathrm{Ca}\left(\mathrm{NO}_{3}\right)_{2}$ can likely be ruled out as Arimoto et al. (2004), reported a molar equivalents ratio of $\mathrm{NO}_{3}^{-} / \mathrm{WS} \mathrm{Ca}^{2+}$ of just 0.008 . The presence of chloride as a function of calcium is not robust $\left(R^{2}=0.05\right)$.

When the degree of aerosol neutralization is plotted against equivalents of calcium (middle-row of Fig. 7), and the data are coloured by scattering Ångstrom exponent, there is generally sufficient ammonium to neutralize most $\mathrm{SO}_{4}^{2-}$ to form $\left(\mathrm{NH}_{4}\right)_{2} \mathrm{SO}_{4}$. Also, ammonium is generally insufficient to create much $\mathrm{NH}_{4} \mathrm{NO}_{3}$ nor is it available to combine with $\mathrm{Cl}^{-}$. Using the method of Jordan et al. (2003a) we plot excess sulfate, excess sulfate plus nitrate and excess sul- fate and nitrate plus chloride, i.e. equivalents of $\mathrm{SO}_{4}^{2-}, \mathrm{NO}_{3}^{-}$ and $\mathrm{Cl}^{-}$which cannot be paired with available $\mathrm{NH}_{4}^{+}$, versus aerosol calcium, in the bottom-row of Fig. 7. The data are accompanied by the $1: 1$ alkalinity line (blue), the regression from Jordan et al. (2003a) (red), a linear regression for the INTEX-B data (black) and a modified linear regression that underweights outliers (dashed-black). Note that the Jordan et al. (2003a) regressions were for near source $\mathrm{Ca}^{2+}$ values that ranged from 100-1000 neq sm ${ }^{-3}$ whereas the INTEX-B concentrations are substantially reduced (max $\sim 130$ neq sm $^{-3}$ ) due to removal processes (Dunlea, 2009), and dilution during long-range transport. The regression for the sum of excess sulfate plus nitrate versus calcium is more significant $\left(R^{2}=0.35\right)$ than that for sulfate alone $\left(R^{2}=0.12\right)$ but each of the regressions which underweight outliers are similarly robust. While there is the potential that sulfate, nitrate and calcium are simply co-emitted at the source, Sullivan et al. (2007a) found ammonium can be associated with sulfate rich submicrometer dust leading to inaccuracy in the Jordan et al. (2003a), assumption that all ammonium is associated with submicrometer sulfate or nitrate. Furthermore, when combined with the potential influence of submicrometer calciumcontaining particulate of anthropogenic origin (e.g. fly ash), the inherent uncertainty in airborne measurements of supermicrometer aerosol (Blomquist et al., 2001; Huebert et al., 2004; McNaughton et al., 2007) as well as ammonium nitrate (Bergin et al., 1997), it is not surprising that these regressions are not very robust. Still, the trends indicate that up to $13 \%$ of the calcite alkalinity could have been consumed by acidic sulfur species, and that $\sim 14 \%$ of the calcite alkalinity has been consumed by acidic nitrogen species. In the absence of dust these secondary aerosol species may have remained in the gas phase or condensed upon the submicrometer particles. When chloride is considered, the modified $R^{2}$ statistic increases slightly, demonstrating that a further $4 \%$ consumption of the calcite alkalinity could be related to heterogeneous reactions between dust and $\mathrm{HCl}$. 

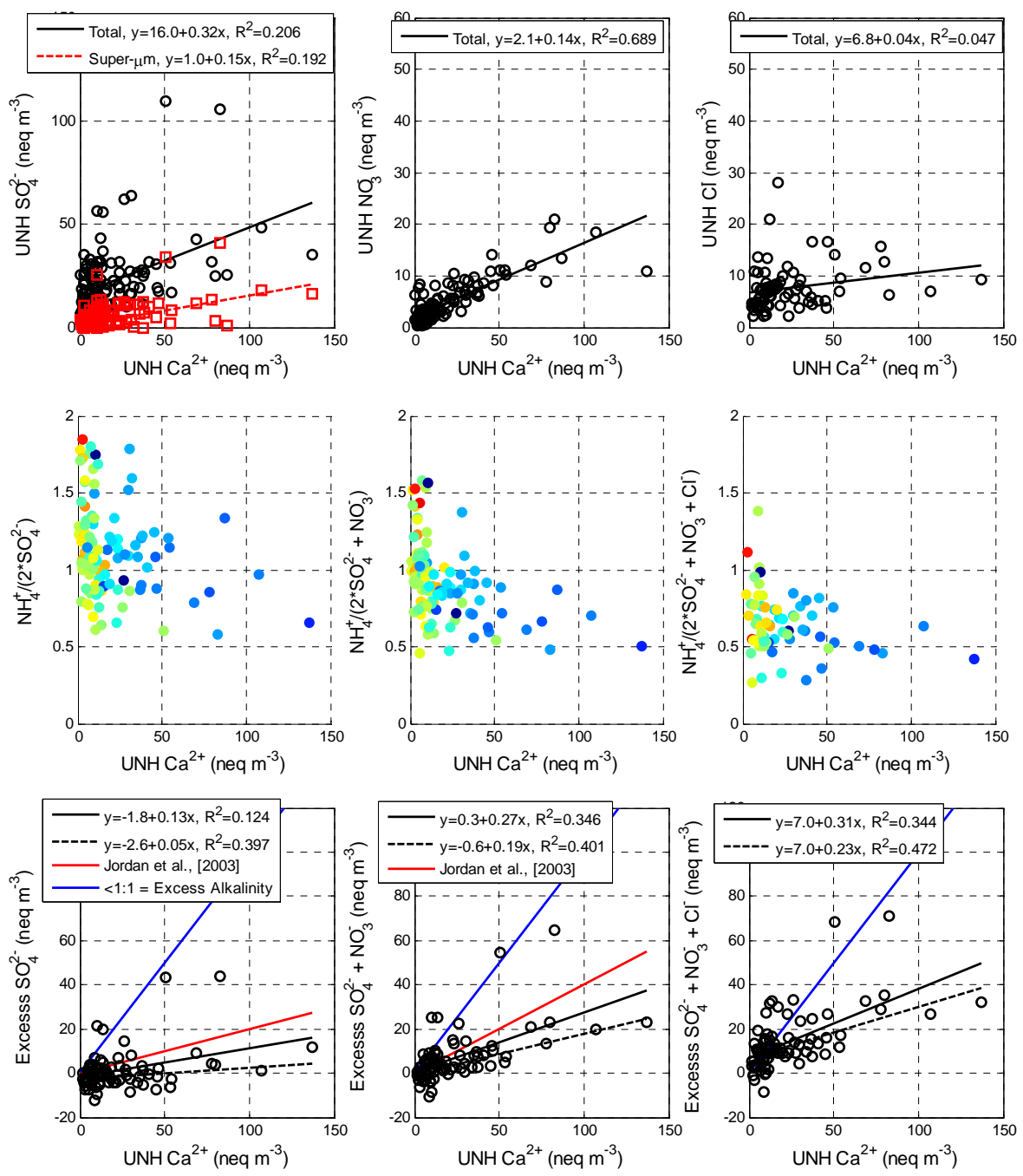

Fig. 7. Linear regression of equivalents of sulfate, nitrate and chloride versus equivalents of calcium (top-row). Neutralization of sulfate, sulfate + nitrate and sulfate + nitrate + chloride by ammonium as a function of equivalents of calcium (middle-row) - data are color coded by scattering ngstrom exponent as per Fig. 6. Excess sulfate, excess sulfate + nitrate, and sulfate + nitrate + chloride plotted versus equivalents of calcium after the method of Jordan et al. (2003a) (bottom row). Data are for total aerosol collected on filters aboard the NASA DC-8 in the free troposphere of the Eastern North Pacific during INTEX-B.
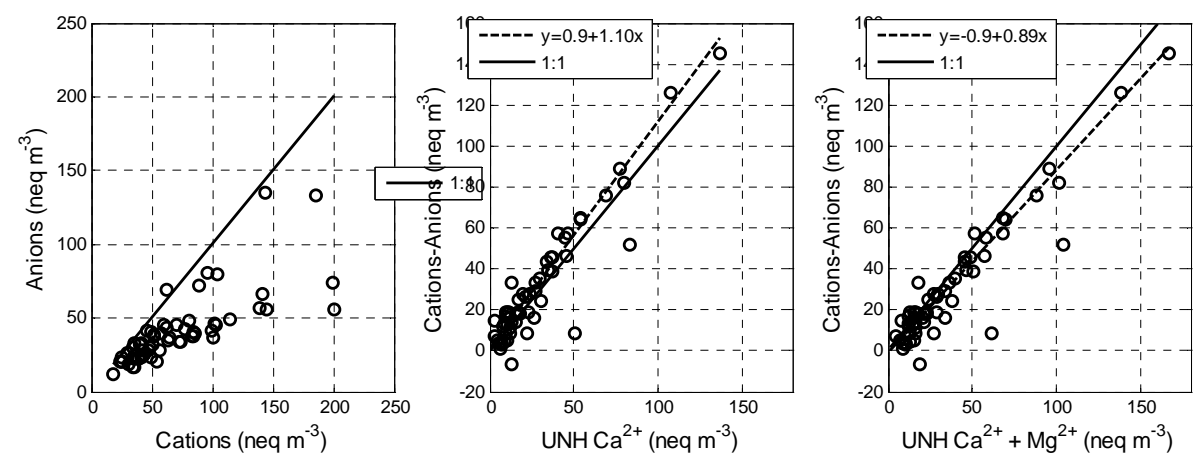

Fig. 8. Ratio of UNH anions to cations (left). Imbalances can be accounted for by assuming that the missing anion is $\mathrm{CO}_{3}^{2-}$ associated with calcite, $\mathrm{CaCO}_{3}$ (center) or dolomite, $\mathrm{CaMg}\left(\mathrm{CO}_{3}\right)_{2}$ (right). 
For irreversible reactions with calcite to account for the increases in aerosol sulfate, nitrate and chloride we need to establish whether or not the $\mathrm{Ca}^{2+}$ measured in the Asian plumes is actually calcite. We have already used the size distribution measurements to derive an $11 \mathrm{wt} \%$ of $\mathrm{CaCO}_{3}$ for the dust aerosol (Fig. 5). The variability of the calcite wt\% in Chinese Loess (3.6-21\%, Liu, 1985) leaves a relatively large margin for error and the $11 \mathrm{wt} \%$ reported here is higher than the near source values $(5-8 \mathrm{wt} \%)$ reported by Kline et al. (2004). The left panel of Fig. 8 plots the anions versus cations for the UNH filter-based chemistry measurements. Minor cations such as $\mathrm{Fe}^{2+}$ are not measured by the UNH IC technique but their concentrations are expected to be a small fraction of the total. Similarly $\mathrm{H}^{+}$is not reported thus the $\mathrm{pH}$ of the aerosol is unknown. The major missing anion in the analysis is $\mathrm{CO}_{3}^{2-}$. Where a large anion/cation imbalance occurs we can assess the probability that the missing ion is $\mathrm{CO}_{3}^{2-}$ by plotting the imbalance vs. $\mathrm{Ca}^{2+}$ (center panel of Fig. 8). A slope of 1:1 would account for carbonate as calcite. Dolomite, $\mathrm{CaMg}\left(\mathrm{CO}_{3}\right)_{2}$, can also be a source of carbonate ions thus we also include a plot versus the sum of the molar equivalents of $\mathrm{Ca}^{2+}+\mathrm{Mg}^{2+}$. For both the Hawaii and Alaska data, large ion imbalances occur up to ratios of $1: 4$. When plotted vs. calcium the imbalance is reduced to within $+10 \%$. When plotted vs. the sum of the calcium and magnesium the imbalance is reduced to within $-11 \%$. An uncertainty of $+/-15 \%$ can be considered the limit of the filter-based measurement technique or the result of missing ions such as $\mathrm{Fe}^{2+}$ and $\mathrm{H}^{+}$. We conclude that the missing anion is most likely $\mathrm{CO}_{3}^{2-}$.

Some of the tropospheric airmasses analyzed above contained mineral dust as well as high concentrations $(>800$ fCi sm ${ }^{-3}$ ) of the stratospheric airmass tracer ${ }^{7} \mathrm{Be}$ (Dibb et al., 2003a; Jordan et al., 2003b). Stratospheric concentrations of $\mathrm{HNO}_{3}(\mathrm{~g})$ are typically higher than those observed in the FT. As a result, Asian dust lofted beyond the tropopause or into a FT airmass that mixes with stratospheric air could potentially be re-exposed to nitric acid. This would result in additional conversion of $\mathrm{HNO}_{3}(\mathrm{~g}) \rightarrow \mathrm{Ca}\left(\mathrm{NO}_{3}\right)_{2}$ in excess of the nitrogen species converted from the emission of anthropogenic precursors (i.e. $\mathrm{NO}_{\mathrm{x}}$ ). However, when excess sulfate plus nitrate is plotted against ${ }^{7} \mathrm{Be}$ there is no clear trend between elevated excess $\mathrm{NO}_{3}^{-}$and ${ }^{7} \mathrm{Be}$ (not shown). Thus the higher slope and more robust correlation between nitrate and dust for the subset of upper troposphere-lower stratosphere samples during INTEX-B cannot be attributed directly to secondary exposure to stratospheric nitric acid. Possible explanations include higher initial concentration of anthropogenic $\mathrm{NO}_{\mathrm{x}}$ mixing with the Asian dust near the source, differing thermodynamic histories for the airmasses (e.g. exposure to high $\mathrm{RH}$ ) and filter-based sample integration times $(5-10 \mathrm{~min})$ longer than that required to analyze fine-scale structure in the tropospheric folds. The results do not preclude the possibility that exposure to stratospheric nitric acid can cause a second set of heterogeneous reactions to take place, but simply that this potential contribution cannot be determined from the INTEX-B measurements.

\subsection{Heterogeneous chemistry in the nitrate-rich bound- ary layer of the Central Mexican Plateau}

The Mexico City airshed is a complex setting with diverse sources of primary aerosol (soot, organics, dust) as well as secondary aerosol precursors $\left(\mathrm{SO}_{2}, \mathrm{NO}_{\mathrm{x}}, \mathrm{VOC}\right.$ 's) (DeCarlo et al., 2008; Molina et al., 2008; Salcedo et al., 2006). A detailed analysis of aerosol in the airshed is beyond the scope of this publication. But, motivated by the success of the heterogeneous chemistry analysis over the remote Pacific, we evaluate the nitrogen rich boundary layer of the Central Mexican Plateau (alt $<2.0 \mathrm{~km}$ AGL), and the FT over the Gulf of Mexico (alt >1.5 AGL), locations where the DC-8 measured the highest concentrations of mineral dust during MILAGRO/INTEX-B.

The top row of Fig. 9 are from the DC- 8 dataset and indicate a poor correlation between sulfate and calcium. The intercept for the regression can be brought to near zero by subtracting submicrometer sulfate, however, the trend with calcium is still not compelling evidence of heterogeneous reactions. The relationship between $\mathrm{NO}_{3}^{-}$and $\mathrm{Ca}^{2+}$ is highly variable but a general trend with perhaps two branches is evident. Total aerosol chloride from the UNH filters show a relatively robust correlation with the measurements of total calcium. However, in contrast to the samples from the Eastern North Pacific, the chloride from the Mexico City samples is not likely of a marine origin. There is generally sufficient ammonium to partially neutralize the sulfate aerosol (middle-row, Fig. 11). This is consistent with other data collected near Mexico City where the submicron mode was typically neutralized by ammonium (Aiken, 2009; DeCarlo et al., 2008; Salcedo et al., 2006). When nitrate and chloride are considered there is insufficient ammonium to neutralize the acid species.

When excess sulfate is plotted versus calcium (bottomrow, Fig. 11) we find large negative values which appear to be associated with relatively fresh fire plumes sampled near Mexico City. The slope and $R^{2}$ of the modified regression do not indicate a trend that is sufficiently different from zero but could indicate the presence of gypsum in the Mexico City dusts. After computing excess sulfate + nitrate, there is sufficient ammonium to form both $\left(\mathrm{NH}_{4}\right)_{2} \mathrm{SO}_{4}$ and $\mathrm{NH}_{4} \mathrm{NO}_{3}$, but insufficient ammonium to consume all the excess acids. The regression against calcium is relatively robust $\left(R^{2}=0.52\right)$ and indicates that $22-30 \%$ of the calcite alkalinity has been consumed through reactions with nitrogen species. Perhaps the most intriguing result is the improved correlation $\left(R^{2}=0.56\right)$ and a further $8 \%$ consumption of calcite alkalinity by chloride over Mexico City. The initial dust composition is a relative unknown, though ratios of $\mathrm{Na}: \mathrm{Ca}$ and $\mathrm{Mg}: \mathrm{Ca}$ are indicative of crustal material rather than sea salt (not shown). The exceptions stand out as the large 

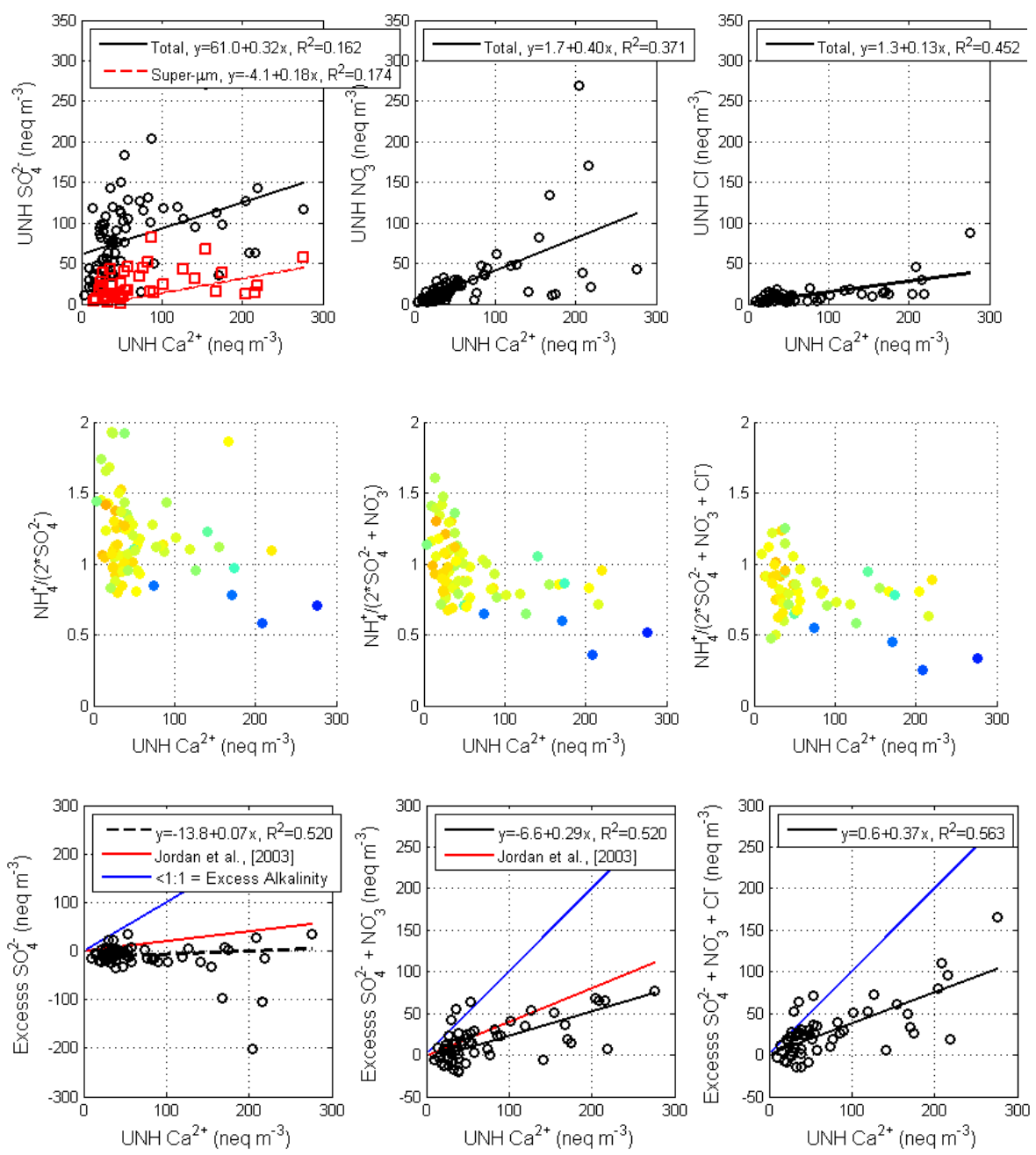

Fig. 9. Same as Fig. 7 but for total aerosol collected on filters aboard the NASA DC-8 in the continental boundary layer of the Central Mexican Plateau and the free troposphere above the Gulf of Mexico.

cation-anion imbalances that do not lie along the 1:1 line in the central and right panels of Fig. 10. These data points have geochemical ratios nearer to sea-salt, likely contain primary salts derived from the dry lake beds of the Central Plateau (e.g. Texcoco (Moffet et al., 2008; Moya et al., 2004), and were visually observed as dust sources (C. Mc Naughton) from on board the DC-8 during INTEX-B.

\subsection{6-2008 record of aerosol chemistry at the Mauna Loa Observatory}

Airborne data collected during a single campaign is effectively a point measurement in both space and time. Here we put the INTEX-B measurements into a broader temporal context by comparing the data to the long-term record from the Mauna Loa Observatory. For the past 13 years the University of Hawaii has conducted measurements of aerosol chemistry at the Mauna Loa Observatory (MLO) (Huebert et al., 2001). The top row of Fig. 11 plots total aerosol sulfate, nitrate and chloride versus aerosol calcium for the 13-year MLO record. Note that the data are colour coded by scattering Angstrom exponent $($ red $=3.0$; blue $=-0.5)$ and that the $y$-axis scales differ. We also include a solid and a dashed line which approximately bound the ranges of values for dust concentrations greater than $20 \mathrm{neq} \mathrm{sm}^{-3}$. The middle row of Fig. 11 plots the degree of neutralization of the acidic aerosol species by ammonium and indicate that aerosol in the FT over the North East Pacific are typically only partially neutralized. Confining our analysis to $\mathrm{Ca}^{2+}$ concentrations greater than $20 \mathrm{neq} \mathrm{sm}^{-3}$ we plot regressions for excess sulfate, sulfate plus nitrate and excess sulfate and nitrate plus chloride. The more comprehensive MLO data set indicates that $19 \%$ of the calcite alkalinity is consumed by sulfuric acid whereas an additional $7 \%$ and $2 \%$ can be ascribed to reactions with nitric and hydrochloric acid. The $2 \%$ increase due to reaction with $\mathrm{HCl}$ is actually not significant as the uncertainty in the slope is $+/-4 \%$. Regressions including oxalate are similar with 

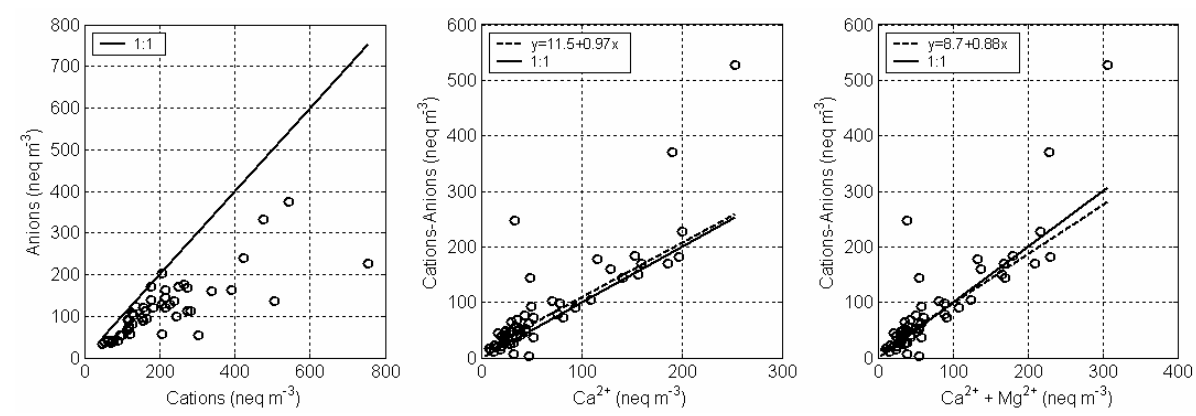

Fig. 10. Same as Fig. 8 but for airmasses in the continental boundary layer of the Central Mexican Plateau and the free troposphere above the Gulf of Mexico.
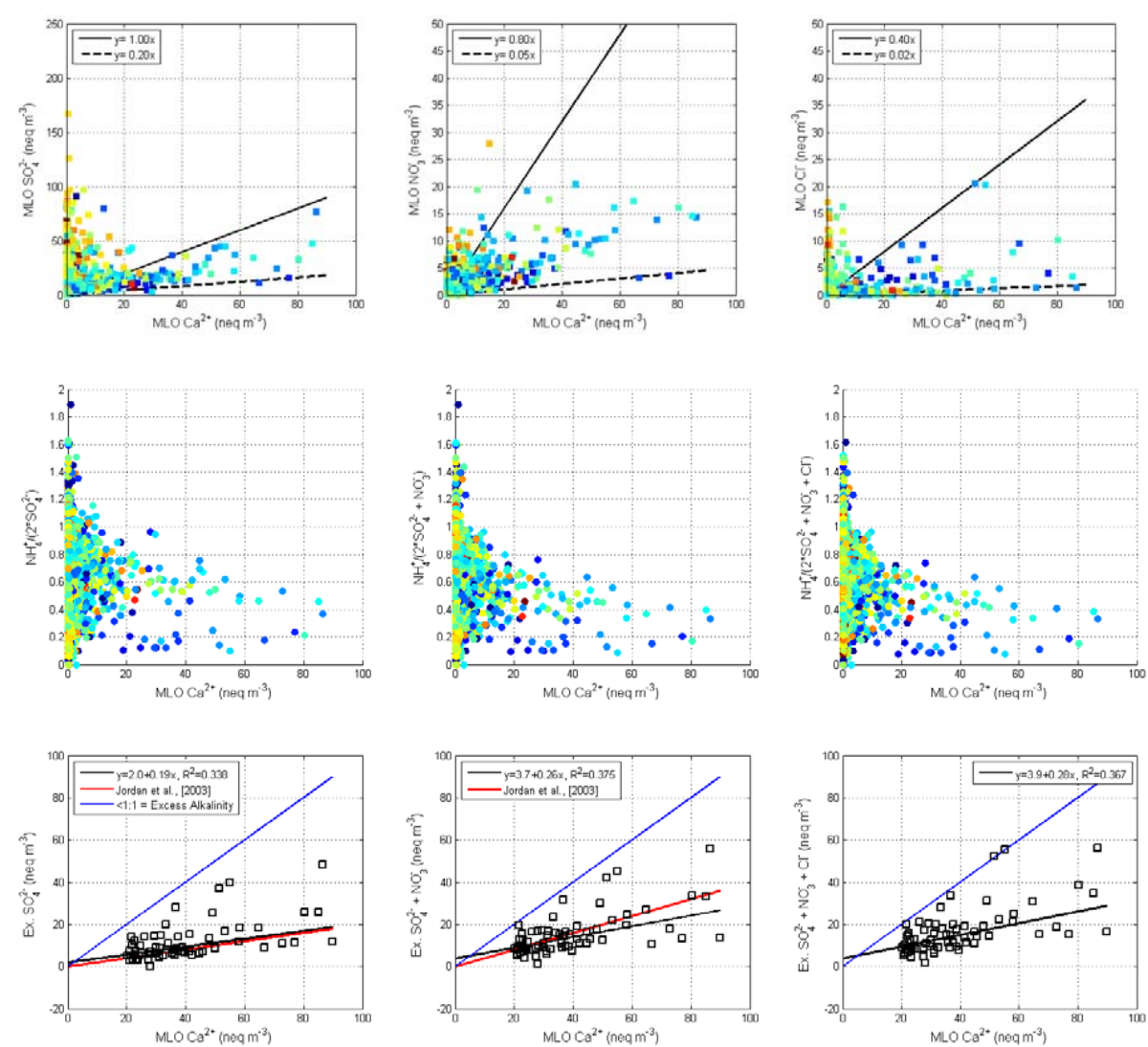

Fig. 11. Total aerosol sulfate, nitrate and chloride versus aerosol calcium for the 13 -year record of filter based measurements at the Mauna Loa Observatory (top-row). Note that the data are shaded by scatteringa angstrom exponent. Scales differ and that the solid and dashed lines are provided as guides to the slope. The middle-row is the degree of neutralization of the acid species by ammonium and are shaded by scattering angstrom exponent. Bottom row compares linear regressions of excess sulfate, suflate plus nitrate, and sulfate, nitrate and chloride versus calcium.

a further $1 \%$ consumption of alkalinity but with an uncertainty in the slope of $+/-4 \%$. And while variability appears to be driven largely by the association between sulfate and calcium, irreversible sequestration of anthropogenically derived nitrate is significant. Finally, Fig. 11 indicates a few cases where reactions approach the 1:1 alkalinity line. It is these instances where the buffering capacity of the $\mathrm{Ca}^{2+}$ as
$\mathrm{CaCO}_{3}$ could have been be exceeded and acid processing of the mineral dust is most likely to have occurred (Solomon et al., 2009). Note however that these cases are the exception ( $\sim 5$ cases) rather than the rule based on the 65 nighttime samples plotted. 

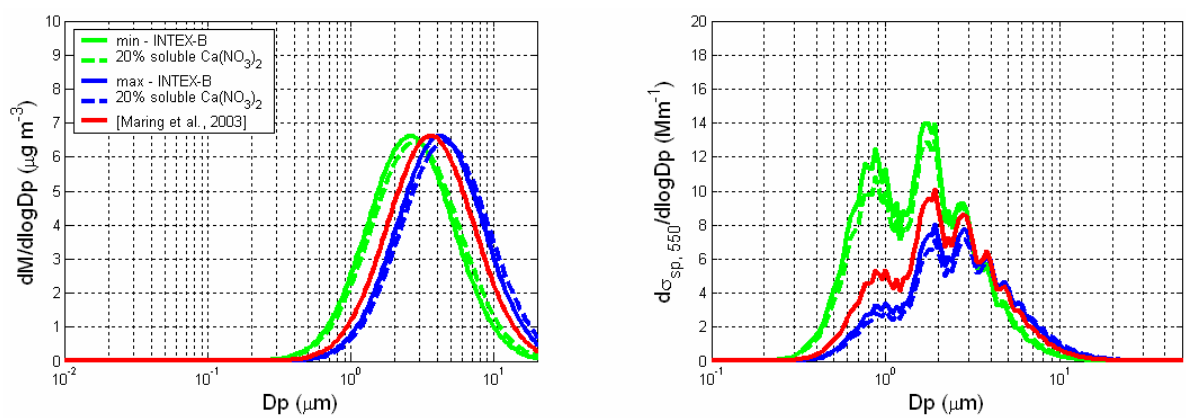

Fig. 12. Negligible increase in volume median diameter (left), and decrease in light scattering (right) as a result of heterogeneous conversion of $20 \mathrm{wt} \%$ of insoluble $\mathrm{CaCO}_{3}$ to soluble $\mathrm{Ca}\left(\mathrm{NO}_{3}\right)_{2}$. Scattering is computed at $90 \% \mathrm{RH}$ and uses a fixed refractive index of $1.53-0.0006 \mathrm{i}$.
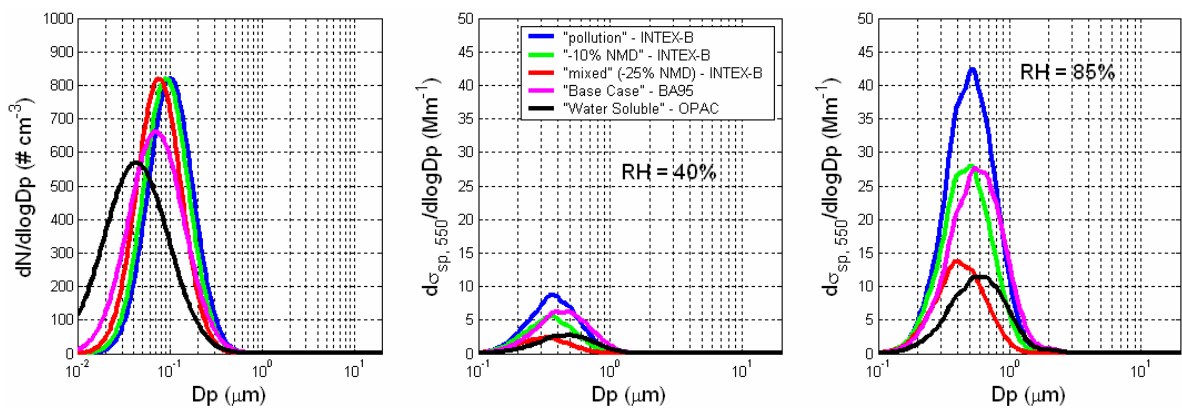

Fig. 13. Number size distributions (left) for INTEX-B data collected in pollution dominated cases (blue), mixed dust and pollution (red) for which there was a 25\% reduction in the NMD. A $10 \%$ reduction in NMD is simulated in green while the base case of (Boucher and Anderson, 1995) is in magenta and the "water soluble" OPAC aerosol (Hess et al., 1998) is in black. Scattering size distributions at 40\% RH (middle) and $80 \%$ RH illustrate the significance of NMD and $g$ on aerosol optical properties in the accumulation mode.

Table 5. Log-normal parameters for distributions in Fig. 13.

\begin{tabular}{lll}
\hline $\mathrm{N}\left(\mathrm{cm}^{-3}\right)$ & $\mathrm{NMD}(\mu \mathrm{m})$ & $\sigma_{g}$ \\
\hline 500 & 0.100 & 1.75 \\
500 & 0.900 & 1.75 \\
500 & 0.075 & 1.75 \\
500 & 0.070 & 2.00 \\
500 & 0.042 & 2.24 \\
\hline
\end{tabular}

\section{Discussion}

\subsection{The effect of heterogeneous reactions on Asian Dust optical properties}

In Fig. 12 we plot the range of mass (volume) distributions for dust (mean $+/-1 \sigma$, in blue and green) measured over the Eastern North Pacific during INTEX-B, as well as a Saharan distribution (red) measured after long-range transport (Maring et al., 2003). The hygroscopic growth factor for $\mathrm{Ca}\left(\mathrm{NO}_{3}\right)_{2}$ at $90 \% \mathrm{RH}$ compared to $40 \% \mathrm{RH}$ is a factor of $\sim 1.5$. Fully consuming $20 \mathrm{wt} \%$ of $\mathrm{CaO}, \mathrm{MgO}$ and $\mathrm{CaCO}_{3}$ to produce $\mathrm{Ca}\left(\mathrm{NO}_{3}\right)_{2}$ would only increase the volumetric mean diameter of the dust distribution from $2.5 \mu \mathrm{m}$ to $\sim 3.0 \mu \mathrm{m}$ between these two RH's. Computing scattering at $550 \mathrm{~nm}$ assuming spherical particles and using Mie theory with a fixed refractive index (1.53-0.0006i (Clarke et al., 2004, Fig. 15b), results in a 7-8\% reduction in light scattering due to a reduction in mass scattering efficiency at larger sizes. This small difference in optical properties is negligible compared to the observed variability in the dust distributions and their composition. Additionally, this change in optical properties is small compared to the uncertainty in predicting ambient $\mathrm{RH}$ in climate models (Petch, 2001).

\subsection{The effect of heterogeneous reactions on pollution aerosol optical properties}

In the previous section we demonstrate that heterogeneous reactions have a negligible effect on dust optical properties compared to their variability in-situ. However, the presence of supermicrometer dust reduces the mass of secondary aerosol species that condense on primary aerosol of anthropogenic origin; a process that is approximately proportional to aerosol surface area (Howell et al., 2006). This significantly reduces the single scattering albedo of the 
Table 6. Comparison of light scattering values for size distributions with three different NMD's at $10 \%, 80 \%$ and $95 \%$ RH.

\begin{tabular}{cccccccc}
\hline NMD $(\mu \mathrm{m})$ & $\sigma_{g}$ & \multicolumn{2}{c}{ Scattering $\left(\mathrm{Mm}^{-1}\right)$ for $\left(\mathrm{NH}_{4}\right)_{2} \mathrm{SO}_{4}$ growth factor at: } & \multicolumn{3}{c}{ Percent Difference } \\
\hline & & $10 \% \mathrm{RH}$ & $80 \% \mathrm{RH}$ & $95 \% \mathrm{RH}$ & $10 \% \mathrm{RH}$ & $80 \% \mathrm{RH}$ & $95 \% \mathrm{RH}$ \\
\hline 0.100 & 1.75 & 6.3 & 16.1 & 46.5 & & & \\
0.090 & 1.75 & 4.1 & 10.8 & 32.5 & $-35 \%$ & $-33 \%$ & $-30 \%$ \\
0.075 & 1.75 & 1.9 & 5.2 & 16.8 & $-70 \%$ & $-67 \%$ & $-64 \%$ \\
\hline
\end{tabular}

Table 7. Error, expressed as a percent difference, between explicit calculations of light scattering assuming an ammonium sulfate composition for three size distributions, compared to scattering values using a fixed $\gamma$, most applicable to the distribution with an NMD of $0.10 \mu$ m.

\begin{tabular}{lllllllllll}
\hline $\mathrm{NMD}(\mu \mathrm{m})$ & sigma_g & \multicolumn{3}{c}{ Scattering for (NH4)2SO4 $\mathrm{g}(\mathrm{RH})$} & \multicolumn{3}{c}{ Scattering for $\gamma=0.76$} & \multicolumn{2}{c}{ Difference $(\%)$} \\
\hline & & $10 \% \mathrm{RH}$ & $80 \% \mathrm{RH}$ & $95 \% \mathrm{RH}$ & $10 \% \mathrm{RH}$ & $80 \% \mathrm{RH}$ & $95 \% \mathrm{RH}$ & $10 \% \mathrm{RH}$ & $80 \% \mathrm{RH}$ & $95 \% \mathrm{RH}$ \\
\hline 0.100 & 1.75 & 6.3 & 16.1 & 46.5 & 6.3 & 19.7 & 56.6 & $23 \%$ & $22 \%$ \\
0.090 & 1.75 & 4.1 & 10.8 & 32.5 & 4.1 & 12.9 & 36.9 & $19 \%$ & $14 \%$ \\
0.075 & 1.75 & 1.9 & 5.2 & 16.8 & 1.9 & 5.9 & 17.0 & $13 \%$ & $1 \%$ \\
\hline
\end{tabular}

accumulation mode aerosol (Clarke et al., 2004) as well as $f(R H)$ (Howell et al., 2006). Here we compare the reduction in ambient light scattering due to a reduction in accumulation mode NMD, to the effect of enriching the accumulation mode in relatively hydrophobic organic species, i.e. a reduction in non-refractory (OM, sulfates and nitrates) accumulation mode mass due to the presence of dust.

The left panel of Fig. 13 shows five number distributions examples. The blue and the red lines are the observations from INTEX-B for the pollution dominated aerosol and for the mixed aerosol types. The green distribution is a simulated distribution with only a $10 \%$ reduction in the pollution NMD. The magenta line is the "base case" from the sensitivity analysis by (Boucher and Anderson, 1995) while the black line is the "water soluble" aerosol type from the popular Optical Properties of Aerosols and Clouds (OPAC) parameterization (Hess et al., 1998). The log-normal fitting parameters used to describe these distributions are found in Table 5. Scattering, calculated at $40 \%$ and $80 \%$ relative humidity, is shown in the middle and right hand plots of Fig. 13. Table 6 compares light scattering for the blue, green and red distributions by evaluating their integrals at $10 \%, 80 \%$ and $95 \%$ RH. From these calculations it is clear that small reductions (10-25\%) in the distributions NMD has a large influence on aerosol optical properties, reducing scattering by as much as $30-70 \%$. This concern is particularly relevant to global climate models that use static aerosol size distributions (e.g. OPAC), or those that use modal or sectional approaches that cannot capture the dynamic nature of the aerosol number distribution.

In Fig. 13 and Table 6 we modeled the optical properties by assigning a growth factor consistent with an ammonium sulfate type composition and by varying the refractive index as a function of $\mathrm{RH}$. The parameter $\gamma$, used in the $\mathrm{f}(\mathrm{RH})$ function (Eq. 1), implicitly incorporates the effects that water uptake, aerosol size, and changing refractive index have on aerosol optical properties. For the pollution distribution with an NMD $0.10 \mu \mathrm{m}$ (blue in Fig. 13), the ammonium sulfate type composition results in a $\gamma$ value of $\sim 0.76$. Strictly speaking it is not appropriate to apply this $\gamma$ to the other two distributions (NMD $=0.090 \mu \mathrm{m}$ and $0.075 \mu \mathrm{m}$ ) as their $\gamma$ values are uniquely dependent on their size distributions and composition. However, Fig. 14 plots the explicitly calculated scattering values as a function of RH compared to those generated using a static $\gamma$ of 0.76 for each distribution. Table 7 tabulates the difference between the static $\gamma$ values compared to the explicitly calculated scattering values at $10 \%, 80 \%$ and $95 \%$ RH. As indicated, the static $\gamma$ method tends to over predict scattering by $\sim 10-25 \%$ at relative humidities below $95 \%$. The static $\gamma$ method does however have an advantage. Since actual aerosol composition, their diameter growth factors $-\mathrm{g}(\mathrm{RH})$, and refractive indices are poorly constrained, we can use the static $\gamma$ approximation to evaluate the effects of size versus composition on aerosol optical properties for these examples.

The INTEX-B, free troposphere, total aerosol, average $\mathrm{f}(\mathrm{RH}) \gamma$ is $0.49-0.52$ (Table 4). This value is effectively identical to the ACE-Asia average 0.51 for fine mode dominated total aerosol (Anderson et al., 2003), indistinguishable from pollution dominated FT values over North America $(0.47+/-0.7)$ (C. Mc Naughton, unpublished data, INTEXNA), but lower than the ACE-Asia value, 0.63 , in the pollution dominated MBL (Carrico et al., 2003). The ACE-Asia 
Table 8. Changes to light scattering at $80 \%$ relative humidity due to a reduction in aerosol number median diameter (blue). These reductions are compared to a reduction in accumulation mode aerosol hygroscopicity from $\gamma=0.5$ to $\gamma=0.48$ (red).

\begin{tabular}{llllllll}
\hline NMD $(\mu \mathrm{m})$ & sigma_g & Scat. at 10\% RH & \multicolumn{2}{c}{ Scattering at 80\% RH } & \multicolumn{3}{c}{ Percentage Difference } \\
\hline & & & $\gamma=0.50$ & $\gamma=0.48$ & Size Only & Comp. Only & Combined \\
\hline 0.100 & 1.75 & 6.3 & 13 & 13 & & & $-3.0 \%$ \\
\hline 0.090 & 1.75 & 4.1 & 8.7 & 8.4 & $-35 \%$ & $-3.0 \%$ & $-37 \%$ \\
\hline 0.075 & 1.75 & 1.9 & 4.0 & 3.9 & $-70 \%$ & & \\
\hline
\end{tabular}

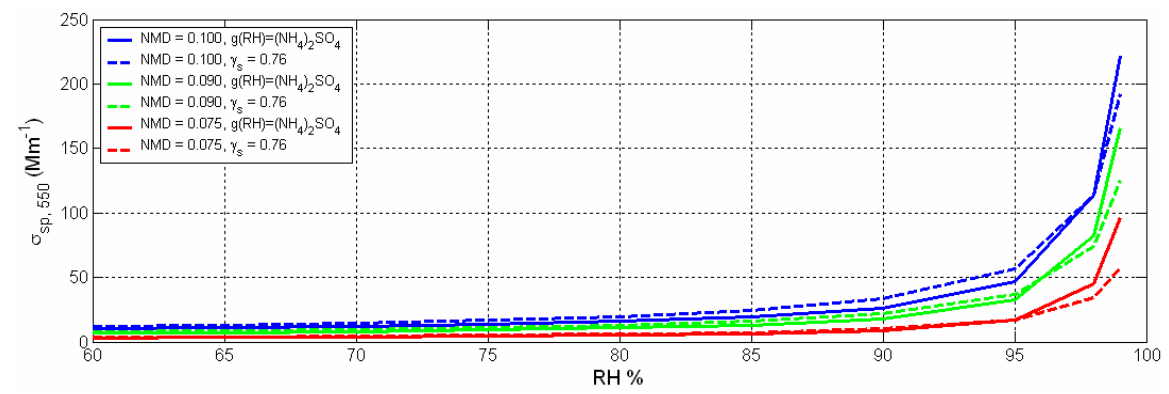

Fig. 14. Comparison of scattering as a function of $\mathrm{RH}$ calculated using Mie theory and assuming an $\left(\mathrm{NH}_{4}\right)_{2} \mathrm{SO}_{4}$ composition and an $\mathrm{RH}$ dependent refractive index (solid lines) for the three distribution in Fig. 13 compared to those using an estimated $\gamma$ of 0.76 (dashed lines).

version of the Quinn et al. (2005) parameterization of $\mathrm{f}(\mathrm{RH})$ $\gamma$,

$\gamma_{s}=0.9-0.7 F_{o}$

allows us to estimate the ratio of particulate organic matter to $\mathrm{POM}+\mathrm{SO}_{4}^{2-}$ according to:

$F_{o}=\frac{C_{o}}{\left(C_{o}+C_{s}\right)}$

where $\mathrm{C}_{o}$ is the mass of POM and $\mathrm{C}_{s}$ is the mass of sulfates. $\mathrm{POM}$ can be further divided into both semivolatile (SVolOM) and refractory (RefOM) organic components (Clarke et al., 2007). For an $\mathrm{f}(\mathrm{RH}) \gamma$ of $0.50, \mathrm{~F}_{o}$ is 0.57 . As discussed in section 4.1 the INTEX-B average refractory volume fraction is $\sim 12-16 \%,+/-7 \%$. Assigning a density of $1.3 \mathrm{~g} \mathrm{~cm}^{-3}$ to both the refractory and semivolatile OM mass material (Slowik et al., 2004) we can break the $\mathrm{C}_{o}=0.57$ term into $\mathrm{C}_{o}=0.09+0.48$ (RefOM $+\mathrm{SVolOM}$ mass). We can now evaluate the effect a $25 \%$ or $50 \%$ reduction in volatile accumulation mode mass ( $\mathrm{SVolOM}+$ sulfates) has on $\mathrm{F}_{o}$ in order to predict the attendant reduction in $\mathrm{f}(\mathrm{RH}) \gamma$. The corresponding values for $\mathrm{F}_{o}$ are 0.58 and 0.60 and result in new $\mathrm{f}(\mathrm{RH}) \gamma$ values of 0.49 and 0.48 . Table 8 briefly summarizes the comparison between reductions in light scattering due to aerosol size compared to changes in composition. A $10-25 \%$ reduction in the size distribution NMD leads to a 30-70\% reduction in light scattering. After reducing the accumulation mode semi-volatile inorganic (i.e. sulfates) and organic mass by $50 \%$, light scattering at $80 \%$ RH only decreases by $\sim 3 \%$. Thus we conclude that reductions in ambient light scattering, due to competition between pollution and dust aerosol surface area for condensing secondary species, is dominated by reductions in median aerosol size, and not changes to accumulation mode aerosol composition.

\subsection{The effect of heterogenous reactions on $\mathrm{NO}_{\mathrm{y}}$}

In Sect. 4 we established that the heterogeneous reactions are occurring between gas-phase nitrogen species (e.g. $\mathrm{HNO}_{3}$, $\mathrm{NO}_{2}$ ) and mineral dust during long-range transport from Asia. These reactions result in the sequestering of gas-phase compounds in the supermicrometer particulate phase. These relations are replotted in Fig. 15 to examine the effect of Asian dust on $\mathrm{NO}_{\mathrm{y}}$. Here $\mathrm{NO}_{\mathrm{y}}$ is defined as the sum of the available in-situ measurements of: $\mathrm{NO}, \mathrm{NO}_{2}, \mathrm{HNO}_{3}$, PNs and ANs. The left panel shows that nitric acid is converted into aerosol nitrate and is reduced to $\sim 20 \%$ of the sum of these two species at high dust concentrations. Pollution dominated airmasses are rich in $\mathrm{NO}_{\mathrm{y}}$ but particulate $\mathrm{NO}_{3}^{-}$is $<\sim 20 \%$ of the total nitrogen species (top-center and right of Fig. 15). As dust mass increases, particulate nitrate is created from $\mathrm{NO}_{\mathrm{y}}$ and becomes a larger fraction (20-40\%) of total nitrogen. Recall that these estimates are somewhat conservative as the DC- 8 measurements of gas-phase $\mathrm{HNO}_{3}$ are likely contaminated with aerosol $\mathrm{NO}_{3}^{-}$(Miyazaki et al., 2005; Zondlo et al., 2003). 

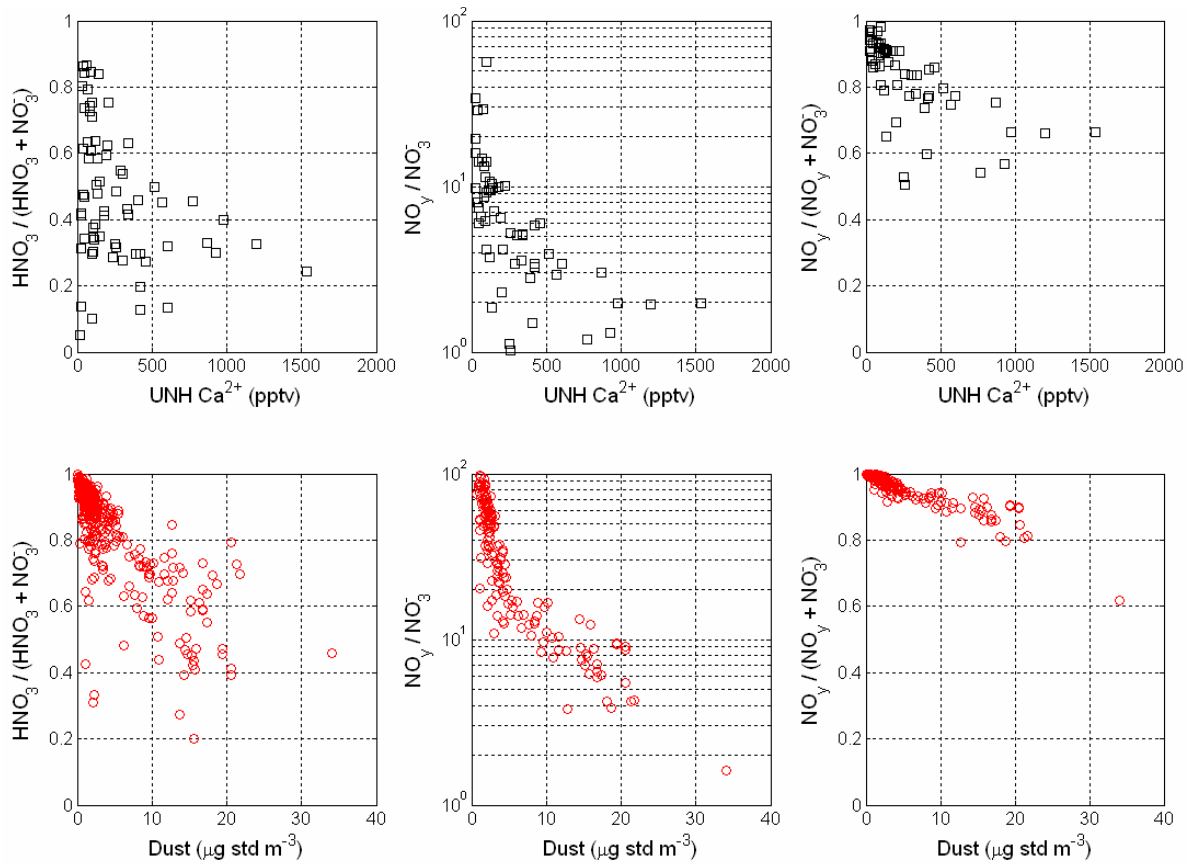

Fig. 15. Upper panels plot nitrogen ratios versus $300-600$ s filter-based chemistry measurements of $\mathrm{Ca}^{2+}$. Using an 11 wt $\% \mathrm{CaCO}_{3}$ and assuming $25 \%$ of the $\mathrm{CaCO}_{3}$ has reacted to form $\mathrm{Ca}\left(\mathrm{NO}_{3}\right)_{2}$, the bottom panels attempt to replicate these relations using fast (60-s avg.) measurements of supermicrometer volume, i.e. mineral "dust" $\left(\pi=2.06 \mathrm{~g} \mathrm{~cm}^{-3}\right)$.

Whereas the filter-based measurements of aerosol chemistry are slow (300-600 s), the HiGEAR size distribution measurements are relatively fast ( 3 seconds). In Fig. 5 we established a robust $\left(R^{2}=0.90\right)$ regression of $11 \mathrm{wt} \%$ for the $\mathrm{CaCO}_{3}$ present in the Asian dust samples. In Fig. 7, 9 and 11 we show that $\sim 5-30 \%$ of the $\mathrm{CaCO}_{3}$ has been consumed by reacting to form $\mathrm{Ca}\left(\mathrm{NO}_{3}\right)_{2}$. Assuming an $11 \mathrm{wt} \%$ for the dust calcite content and $25 \%$ consumption of this alkalinity, we explore the ratios of aerosol nitrate to $\mathrm{HNO}_{3}$ and $\mathrm{NO}_{\mathrm{y}}$ using 60-second averages of $\mathrm{HNO}_{3}, \mathrm{NO}_{\mathrm{y}}$ and supermicrometer dust. Data are restricted to the Pacific free troposphere (alt. $>2.0 \mathrm{~km}, \mathrm{O}_{3}<200 \mathrm{ppbv}$ ), west of $125^{\circ} \mathrm{W}$ where fast (90second) submicrometer sulfate (UNH mist chamber) concentrations are above $1.0 \mu \mathrm{g} \mathrm{sm}^{-3}$. The results of this simulation are shown in the bottom panels of Fig. 15 using red circles. In general we have replicated the shape of the measured relation. The main discrepancy is that the simulated ratios have values higher than those observed using the slower chemistry measurements. This can be attributed to the fact that the tail of the dust distribution has been shown to extend below the $1-\mu \mathrm{m}$ cut size used to isolate the supermicrometer dust and nitrate mass (see also Clarke et al., 2004). Also note that the use of $25 \%$ conversion of the $\mathrm{CaCO}_{3}$ is nearly an upper bound and that some nitrate is present as submicrometer $\mathrm{NH}_{4} \mathrm{NO}_{3}$ and has not been accounted for.
We can also examine these relationships using the fast chemistry measurements from the NSF/NCAR C-130 collected off the US west coast during INTEX-B. The nitrogen ratios are shown in the upper three panels of Fig. 16 for measurements aboard the C-130. These data are stratified using the same criteria as Dunlea et al. (2009), but do not show the same characteristics as the INTEX-B data (e.g. reduction in $\mathrm{NO}_{\mathrm{y}}$ :total nitrogen versus $\mathrm{Ca}^{2+}$ or dust). The reason for this difference is that, although fast, the HR-ToF-AMS only measures non-refractory $\mathrm{NO}_{3}^{-}$in the submicrometer mode, whereas most $(\sim>70 \%)$ of the nitrate is dust-bound in the supermicrometer mode (Kline et al., 2004). Still, the far right panel of Fig. 16 shows an interesting trend in the AMS measurements of $\mathrm{NO}_{3}^{-}$. There is a slight reduction of $\mathrm{NO}_{\mathrm{y}}$ :total nitrogen as a function of dust mass. This could be attributed to $\mathrm{Ca}\left(\mathrm{NO}_{3}\right)_{2}$ detected by the HR-ToF-AMS below $1.0-\mu \mathrm{m}$, in the lower-tail of the dust distribution. As in Fig. 15, we can estimate coarse-mode nitrate using the fast size distribution measurements aboard the C-130. This is shown in the bottom three panels of Fig. 16 and is an approximation to the chemistry-based measurements presented in the top row of Fig. 15.

The upper panel from Fig. 15 and the lower panel from Fig. 16 give us the most complete picture of the heterogeneous reactions we have observed. The observations support the findings of Song and Carmichael (2001) and Bian and Zender (2003), both of whom estimate that heterogeneous reactions in the presence of dust reduces $\mathrm{HNO}_{3}$ by $>50 \%$. 
Second, the presence of dust irreversibly sequesters $\mathrm{NO}_{\mathrm{y}}$ species in the particulate phase. Without dust $\left(<5 \mu \mathrm{g} \mathrm{sm}^{-3}\right)$ $\mathrm{NO}_{\mathrm{y}}$ accounts for $\sim>85 \%$ of the total nitrogen. When dust concentrations exceed $\sim 10 \mu \mathrm{g} \mathrm{sm}^{-3}$, supermicrometer nitrate formation reduces the $\mathrm{NO}_{\mathrm{y}}$ fraction such that it accounts for $60-80 \%$ of total nitrogen. This is in good agreement with Phadnis and Carmichael (2000) who predicted that "the presence of dust (increases) particle nitrate levels in East Asia by $\sim 40 \% "$.

\section{Conclusions}

In spring 2006 the NASA DC-8 and the NSF/NCAR C-130 measured trace-gases and aerosol over Mexico and the Eastern North Pacific as part of MILAGRO and INTEX-B. Airmasses transported long-range from East Asia were sampled in the free troposphere and found to contain Asian pollution and Asian pollution mixed with dust. Accumulation mode and supermicrometer size distributions are summarized and fit using log-normal functions. The presence of dust is found to reduce the median diameter of the accumulation mode aerosol by up to $25 \%$ due to competition for condensing secondary aerosol species. Adding secondary aerosol mass to the supermicrometer mode through condensation and/or heterogeneous reactions has a negligible effect on dust hygroscopicity and optical properties. However, altering the median diameter of the accumulation mode aerosol by $10-25 \%$ can reduce light scattering values by factors of $30-70 \%$ at $80 \%$ relative humidity. Accounting for the relative enrichment of hydrophobic species in dust-influenced accumulation mode aerosol results in a further reduction in light scattering of $\sim 3 \%$ at $80 \%$ relative humidity. Thus we conclude that the reduction in accumulation mode aerosol size, and not subtle changes to its composition, dominates the effect of mineral dust on accumulation mode aerosol optical properties. In order to better predict the influence of heterogeneous reactions on aerosol direct and indirect effects, climate modelers are encouraged to improve the dynamic representation of the aerosol size distribution and include source dependent chemical composition.

Recent modeling studies have been found to make incorrect assumptions regarding the solubility of Asian dust. Literature review, and in-situ measurements presented here, supports a $\mathrm{CaCO}_{3} \mathrm{wt} \%$ of between 3.6 and $21 \%$ with an average value near $12 \%$ for natural Asian dust aerosol. The remaining mineral dust is composed of aluminosilicates and metal-oxides whose water uptake and activation in cloud is a strong function of size, aggregate composition, and exposure to reactive sulfur and nitrogen compounds (Grassian, 2001; Kelly et al., 2007; Matsuki et al., 2009). TRACE-P (Jordan et al., 2003a], ACE-Asia (Kline et al., 2004), MILAGRO and INTEX-B results, as well as long-term measurements at Mauna Loa Observatory show that only $5-30 \%$ of the $\mathrm{CaCO}_{3}$ present in Asian dust is consumed to form more soluble $\mathrm{Ca}\left(\mathrm{NO}_{3}\right)_{2}$. As a result, only $1.2-3.6 \%$ of the dust mass could be considered "soluble" due to heterogeneous reactions. A further consumption of $\sim 2-4 \%$ of the calcite alkalinity can be attributed to reactions with $\mathrm{HCl}$ over the Pacific with as much as $8 \%$ occurring in the boundary layer near Mexico City.

Reacting $\mathrm{NO}_{2}$ and/or $\mathrm{HNO}_{3}$ with $\mathrm{CaCO}_{3}$ results in an irreversible sequestering of gas-phase nitrogen species into the particulate phase. In the presence of dust, nitric acid concentrations are reduced to $<50 \%$ of total nitrate (nitric acid plus particulate nitrate). $\mathrm{NO}_{\mathrm{y}}$ as a fraction of total nitrogen (NOy plus particulate nitrate), is reduced from $>85 \%$ to $60-80 \%$ in the presence of dust. These observations may have a number of implications for atmospheric oxidants which deserve further study.

Acknowledgements. We gratefully acknowledge M. Avery for providing DC-8 measurements of $\mathrm{O}_{3}$. We appreciate the use of Barry Huebert's MLO data, which was collected under NSF grants ATM01-04532 and ATM04-41274. This research was funded under NASA Grant: NNG06GA90G and NSF Grant: ATM05-11521. $E D, P F D$, and $J L J$ were supported by NASA grant NNG06GB03G and NSF grant ATM-0513116. We would also like to acknowledge J. Kelly, R. Sullivan and C. Zender for their constructive reviews of the original manuscript. This is SOEST publication number 7622 .

Edited by: H. Singh

\section{References}

Aiken, A. C., Salcedo, D., Cubison, M. J., Huffman, J. A., DeCarlo, P. F., Ulbrich, I. M., Docherty, K. S., Sueper, D., Kimmel, J. R., Worsnop, D. R., Trimborn, A., Northway, M., Stone, E. A., Schauer, J. J., Volkamer, R. M., Fortner, E., de Foy, B., Wang, J., Laskin, A., Shutthanandan, V., Zheng, J., Zhang, R., Gaffney, J., Marley, N. A., Paredes-Miranda, G., Arnott, W. P., Molina, L. T., Sosa, G., and Jimenez, J. L.: Mexico City aerosol analysis during MILAGRO using high resolution aerosol mass spectrometry at the urban supersite (T0) - Part 1: Fine particle composition and organic source a pportionment, Atmos. Chem. Phys., 9, 66336653, 2009, http://www.atmos-chem-phys.net/9/6633/2009/.

Alfaro, S. C., Gomes, L., Rajot, J. L., Lafon, S., Gaudichet, A., Chatenet, B., Maille, M., Cautenet, G., Lasserre, F., Cachier, H., and Zhang, X. Y.: Chemcial and optical characterizatino of aerosols measured in spring 2002 at the ACE-ASia supersite, Zhenbeitai, China, J. Geophys. Res., 108 (D23), 8641, doi:10.1029/2002JD003214, 2003.

Anderson, T., Masonis, S. J., Covert, D. S., Ahlquist, N. C., Howell, S., Clarke, A. D., and McNaughton, C. S.: Variability of aerosol optical properties derived from in-situ aircraft measurements during ACE-Asia, J. Geophys. Res., 108(D23), 8647, doi:10.1029JD003247, 2003.

Anderson, T. L., Covert, D. S., Marshall, S. F., Laucks, M. L., Charlson, R. J., Waggoner, A. P., Ogren, J. A., Caldow, R., R. L. Holm, F. R. Quant, G. J. Sem, A. Wiedensohler, N. A. Ahlquist, and T. S. Bates, Performance characteristics of a high-sensitivity, three-wavelength, total scatter/backscatter nephelometer, J. Atmos. Ocean. Technol., 13(5), 967-986, 1996. 
Anderson, T. L. and Ogren, J. A.: Determining aerosol radiative properties using a TSI 3563 integrating nephelometer, Aerosol Sci. Technol., 29, 57-69, 1998.

Andreae, M. O. and Crutzen, P. J.: Atmospheric Aerosols: Biogeochemical Sources and Role in Atmospheric Chemistry, Science, 276(5315), 1052-1058, 1997.

Archuleta, C. M., DeMott, P. J., and Kreidenweis, S. M.: Ice nucleation by surrogates for atmospheric mineral dust andmineral dust/sulfate particles at cirrus temperatures, Atmos. Chem. Phys., 5, 2617-2634, 2005.

Arimoto, R., Kim, Y. J., Quinn, P. K., Bates, T. S., Anderson, T. L., Gong, S., Uno, I., Chin, M., Huebert, B. J., Clarke, A. D., Shinozuka, Y., Weber, R. J., Anderson, J. R., Guazzotti, S. A., Sullivan, R. C., Sodeman, D. A., Prather, K. A., and Sokolik, I. N.: Characterization of Asian Dust during ACE-Asia, Global Planet. Change, 52(1-4), 23-53, 2006.

Arimoto, R., Zhang, X. Y., Huebert, B. J., Kang, C. H., Savoie, D. L., Prospero, J. M., Sage, S. K., Schloesslin, C. A., Khaing, H. M., and Oh, S. N.: Chemical composition of atmospheric aerosols from Zhenbeitai, China and Gosan, South Korea, during ACE-Asia, J. Geophys. Res., 109, D19S04, doi:10.1029/2003JD004323, 2004.

Baron, P. A. and Willeke, K.: Aerosol Measurement: Principles, techniques, and applications, second edition, John Wiley and Sons Inc., 2001.

Bauer, S. E. and Koch, D.: Impact of heterogeneoussulfate formation at mineral dust surfaces on aerosol loads and radiative forcing in the Goddard Institute for Space Studies general circulation model, J. Geophys. Res., 110, D17202, doi:10.1029/2005JD005870, 2005.

Bauer, S. E., Mishchenko, M. I., Lacis, A. A., Zhang, S., Perlwitz, J., and Metzger, A. M.: Do sulfate and nitrate coatings on minearl dust have important effects on radiative properties and climate modelling?, J. Geophys. Res., 112, D06307, doi:10.1029/2005JD006977, 2007.

Bergin, M. H., Ogren, J. A., Schwartz, S. E., and McInnes, L. M.: Evaporation of ammonium nitrate aerosol in a heated nephelometer: Implications for field measurements, Environ. Sci. Technol., 31(10), 2878-2883, 1997.

Bian, H. and C. S. Zender: Mineral dust and global tropospheric chemistry: Relative roles ofphotolysis and heterogeneous uptake, J. Geophys. Res., 108(D21), 4672, doi:10.1029/2002JD003143, 2003.

Blomquist, B.W., B.J. Huebert, S.G. Howell, M.R. Litchy, C.H. Twohy, A. Schanot, D. Baumgardner, B. Lafleur, R. Seebauch, and M.L. Laucks, An evaluation of the community aerosol inlet for the NCAR C-130 research aircraft, J. Atmos. Ocean. Technol., 18 (8), 1387-1397, 2001.

Bond, T. C., Bussemer, M., Wehner, B., Keller, S., Charlson, R. J., and Heintzenberg, J.: Light absorption by primary particle emissions from a lignite burning plant, Environ. Sci. Technol., 33(21), 3887-3891, 1999.

Boucher, O. and Anderson, T. L.: General circulation model assessment of the sensitivity of direct climate forcing by anthropogenic sulfate aerosols to aerosol size and chemistry, J. Geophys. Res., 100(D12), 26117-26134, 1995.

Brock, C. A., Sullivan, A. P., Peltier, R. E., Weber, R. J., Wollny, A. G., Gouw, J. A. d., Middlebrook, A. M., Atlas, E. L., Stohl, A., Trainer, M. K., Cooper, O. R., Fehsenfeld, F. C., Frost, G.
J., Holloway, J. S., Hubler, G., Neuman, J. A., Ryerson, T. B., Warneke, C., and Wilson, J. C.: Sources of particulate matter in the northeastern United States in summer: 2. Evolution of chemical and microphysical properties, J. Geophys. Res., 113, D08302, doi:10.1029/2007JD009241, 2008.

Canagaratna, M. R., Jayne, J. T., Jimenez, J. L., Allan, J. D., Alfarra, M. R., Zhang, Q., Onasch, T. B., Drewnick, F., Coe, H., Middlebrook, A., Delia, A. E., Williams, L. R., Trimborn, A., Northway, M. J., DeCarlo, P. F., Kolb, C. E., Davidovits, P., and Worsnop, D. R.: Chemical and Microphysical Characterization of Ambient Aerosols with the Aerodyne Aerosol Mass Spectrometer, Mass Spectrom. Rev., 26, 185-222, 2007.

Carrico, C. M., Kus, P., Rood, M. J., Quinn, P. K., and Bates, T. S.: Mixtures of pollution, dust, sea salt, and volcanic aerosol during ACE-Asia: Radiative properties as a function of relative humidity, J. Geophys. Res., 108 (D23), ACE 18-1-ACE 18-18, 2003.

Charlson, R. J., Schwartz, S. E., Hales, J. M., Cess, R. D., Coakley, J. A., Hansen, J. E., and Hofmann, D. J.: Climate Forcing by Anthropogenic Aerosols, Science, 255(5043), 423-430, 1992.

Chen, F. H., Shi, Q., and Wang, J. M.: Environmental changes documented by sedimentation of Lake Yiema in arid China since Late Glaciation, J. Paleolimnol., 22, 159-169, 1999.

Clarke, A. D.: A thermo-optic technique for in situ analysis of sizeresolved aerosol physicochemistry, Atmos. Environ., 25A, 635644, 1991.

Clarke, A. D., Collins, W. G., Rasch, P. J., Kapustin, V. N., Moore, K., Howell, S., and Fuelberg, H. E.: Dust and pollution transport on global scales: Aerosol measurements and model predictions, J. Geophys. Res., 106(D23), 32555-32570, 2001.

Clarke, A.D., C. McNaughton, V.N. Kapustin, Y. Shinozuka, S. Howell, J. Dibb, J. Zhou, B. Anderson, V. Brekhovskikh, H. Turner, and M. Pinkerton, Biomass burning and pollution aerosol over North America: Organic components and their influence on spectral optical properties and humidification response, J. Geophys. Res., 112, D12S18, doi:10.1029/2006JD007777, 2007.

Clarke, A. D., Shinozuka, Y., Kapustin, V. N., Howell, S., Huebert, B., Doherty, S., Anderson, T., Covert, D., Anderson, J., Hua, X., Moore, I. K. G., McNaughton, C., Carmichael, G., and Weber, R.: Size distributions and mixtures of dust and black carbon aerosol in Asian outflow: Physiochemistry and optical properties, J. Geophys. Res., 109(D15), 1-20, 2004.

Clarke, A.D., T. Uehara, and J.N. Porter, Atmospheric nuclei and related aerosol fields over the Atlantic: Clean subsiding air and continental pollution during ASTEX, J. Geophys. Res.-Atmos., 102(D21), 25281-25292, 1997.

Clarke, A. D., Varner, J. L., Eisele, F., Mauldin, R. L., Tanner, D., and Litchy, M.: Particle production in the remote marine atmosphere: Cloud outflow and subsidence during ACE 1, J. Geophys. Res.-Atmos., 103(D13), 16397-16409, 1998.

Cohen, D. D., Garton, D., Stelcer, E., Hawas, O., Want, T., Poon, S., Kim, J., Choi, B. C., Oh, S. N., Sin, H.-J., Ko, M. Y., and Uematsu, M.: Multielemental analysis and characterization of fine aerosols at several key ACE-Asia sites, J. Geophys. Res., 109, D19S12, doi:10.1029/2003JD003569, 2004.

Craig., R. F.: Soil Mechanics, E \& FN Spon, New York, USA, 1997.

Crounse, J. D., McKinney, K. A., Kwan, A. J., and Wennberg, P. O.: Measurement of gas-phase hydroperoxides by chemical ionization mass spectrometry (CIMS), Anal. Chem., 78, 6726-6732, 
2006.

Dai, A., Fung, I., and Genio, A. D. D.: Surface observed global land precipitiation variations during 1900-1988, J. Climate, 10, 2943-2962, 1997.

Davis, D. D., Chen, G., Crawford, J. H., Liu, S., Tan, D., Sandholm, S. T., Jing, P., Cunnold, D. M., DiNunno, B., Browell, E. V., Grant, W. B., Fenn, M. A., Anderson, B. E., Barrick, J. D., Sachse, G. W., Vay, S. A., Hudgins, C. H., Avery, M. A., Lefer, B., Shetter, R. E., Heikes, B. G., Blake, D. R., Blake, N., Kondo, Y., and Oltmans, S.: An assessment of western North Pacific ozone photochemistry based on springtime observations from NASA's PEM\&hyphen; West B (1994) and TRACE\&hyphen;P (2001) field studies, J. Geophys. Res., 108(D21), GTE 50-1GTE 50-18, 2003.

Day, D. A., Wooldridge, P. J., Dillon, M. B., Thornton, J. A., and Cohen, R. C.: A thermal dissociation laser-induced fluorescence instrument for in-situ detection of NO2, peroxy nitrates, alkyl nitrates, and $\mathrm{HNO}_{3}$, J. Geophys. Res., 107(D6), doi:10.1029/2001JD000779, 2002.

DeCarlo, P. F., Dunlea, E. J., Kimmel, R. E., Aiken, A. C., Sueper, D. T., Crounse, J. D., Wennberg, P. O., Emmons, L., Shinozuka, Y., Clarke, A. D., Zhou, J. C., Tomlinson, J. M., Collins, D., Knapp, D., Weinheimer, A., Campos, T., and Jimenez, J. L.: Fast airborne aerosol size and chemistry measurements above Mexico City and Central Mexico during the MILARGRO campaign, Atmos. Chem. Phys., 8, 4027-4048, 2008.

DeCarlo, P. F., Kimmel, R. E., Trimborn, A., Northway, M. J., Jayne, J. T., Aiken, A. C., Gonin, M., Fuhrer, K., Horvath, T., Docherty, K. S., Worsnop, D. R., and Jimenez, J. L.: Field-Deployable, High-Resolution, Time-of-Flight Aerosol Mass Spectrometer, Anal. Chem., 78, 8281-8289, 2006.

DeCarlo, P.F., J.G. Slowik, D.R. Worsnop, P. Davidovits, and J.L. Jimenez, Particle Morphology and Density Characterization by Combined Mobility and Aerodynamic Diameter Measurements. Part 1: Theory, Aerosol Sci. Technol., 38, 1185-1205, 2004.

Dentener, F., Carmichael, G. R., Zhang, Y., Lelieveld, J., and Crutzen, P. J.: Role of mineral aerosol as a reactive surface in the global troposphere, J. Geophys. Res., 101(D17), 22869-22889, 1996.

Dentener, F., Kinne, S., Bond, T., Boucher, O., Cofala, J., Generoso, S., Ginoux, P., Gong, S., Hoelzemann, J. J., Ito, A., Marelli, L., Penner, J. E., Putaud, J. P., Textor, C., Schulz, M., van der Werf, G. R., and Wilson, J.: Emissions of primary aerosol and precursor gases in the years 2000 and 1750, prescribed data-sets for AeroCom, Atmos. Chem. Phys. Discuss., 6, 2703-2763, 2006, http://www.atmos-chem-phys-discuss.net/6/2703/2006/.

Derbyshire, E.: On the morphology, sediments, and origin of the Loess Plateau of centratl China, in: Mega-geomorphology, edited by: Gardner, R. and Scoging, H., Clarendon Press, Oxford, 172-194, 1983.

Dibb, J. E., Talbot, R. W., Lefer, B. L., Scheuer, E., Gregory, G. L., Browell, E. V., Bradshaw, J. D., Sandholm, S. T., and Singh, H. B.: Distributions of beryllium-7 and lead-210 over the wesern Pacific: PEM West B, J. Geophys. Res., 102, 28287-28302, 1997.

Dibb, J. E., Talbot, R. W., Scheuer, E., Seid, G., DeBell, L., Lefer, B., and Ridley, B.: Stratospheric influence on the northern North American free troposphere during TOPSE: $7 \mathrm{Be}$ as a stratospheric tracer, J. Geophys. Res., 108(D4), TOP 11-1-TOP 11-8, 2003a.

Dibb, J. E., Talbot, R. W., Scheuer, E. M., Seid, G., Avery, M. A., and Singh, H. B.: Aerosol chemical composition in Asian continental outflow during the TRACE-P campaign: Comparison with PEM-West B, J. Geophys. Res., 108(D21), GTE 36-1-GTE 3613, 2003b.

Ding, Z. L., Sun, J. M., Yang, S. L., and Liu, T. S.: Geochemistry of the Pliocene red clay formation in the Chinese Loess Plateau and implications for its origin, source provenance and palioclimate change, Geochim. Cosmochim. Acta, 65 (6), 901-913, 2001.

Dunlea, E. J., DeCarlo, P. F., Aiken, A. C., Kimmel, J. R., Peltier, R. E., Weber, R. J., Tomlinson, J., Collins, D. R., Shinozuka, Y., McNaughton, C. S., Howell, S. G., Clarke, A. D., Emmons, L. K., Apel, E. C., Pfister, G. G., van Donkelaar, A., Martin, R. V., Millet, D. B., Heald, C. L., and Jimenez, J. L.: Evolution of Asian aerosols during transpacific transport in INTEX-B, Atmos. Chem. Phys., 9, 7257-7287, 2009,

http://www.atmos-chem-phys.net/9/7257/2009/.

Eastwood, M. L., Cremel, S., Gehrke, C., Girard, E., and Bertram, A. K.: Ice nucleation on mineral dust particles: Onset conditions, nucleation rates and contact angles, J. Geophys. Res., 113, D22203, doi:10.1029/2008JD010639, 2008.

Eastwood, M. L., Cremel, S., Wheeler, M., Murray, B. J., Girard, E., and Bertram, A. K.: Effects of sulfuric acid and ammonium sulfate coatings on the ice nucleation properties of kaolinite particles, Geophys. Res. Lett., 36, L02811, doi:10.1029/2008GL035997, 2009.

Fan, S.-M., Horowitz, L. W., Levy II, H., and Moxim, W. J.: Impact of air pollution on wet deposition of mineral dust aerosols, Geophys. Res. Lett., 31 L02104, doi:10.1029/2003GL018501, 2004.

Fast, J. D., de Foy, B., Acevedo Rosas, A., Caetano, E., Carmichael, G., Emmons, L., McKenna, D., Mena, M., Skamarock, W. C., Tie, X., Coulter, R., Barnard, J. C., Wiedinmyer, C., and Madronich, S.; A meteorological overview of the MILAGRO field campaigns, Atmos. Chem. Phys., 7, 2233-2257, 2007.

Fuller, K.A., W.C. Malm, and S.M. Kreidenweis, Effects of mixing on extinction by carbonaceous particles, J. Geophys. Res., 104(D13), 15941-15954, 1999.

Ginoux, P., M. Chin, I. Tegen, J.M. Prospero, B. Holben, O. Dubovik, and S. Lin, Sources and distributions of dust aerosol simulated with the GOCART model, J. Geophys. Res., 106 (D17), 20255-20273, 2001.

Grassian, V. H.: Heterogeneous uptake and reaction of nitrogen oxides and volatile organic compounds on the surface of atmospheric particles including oxides, carbonates, soot and mineral dust: Implications for the chemical balance of the troposphere, Int. Rev. Phys. Chem., 20(3), 467-548, 2001.

Hand, J. L., and Kreidenweis, S. M.: A new method for retrieving particle refractive index and effective density from aerosol size distribution data, Aerosol Sci. Technol., 36, 1012-1026, 2002.

Harvey, M.: The iron CLAW, Environ. Chem., 4, 396-399, 2007.

Hess, M., Koepke, P., and Schult, I.: Optical properties of aerosols and clouds: The software package OPAC, B. Am. Meteor. Soc., 79(5), 831-844, 1998.

Howell, S. G., Clarke, A. D., Shinozuka, Y., Kapustin, V. N., McNaughton, C. S., Huebert, B. J., Doherty, S., and Anderson, T.: The Influence of relative humidity upon pollution and dust during ACE-Asia: size distributions and implications for optical properties, J. Geophys. Res., 111, D06205, 
doi:10.1029/2004JD005759, 2006.

Huebert, B. J., Howell, S. G., Covert, D. S., Bertram, T., Clarke, A. D., Anderson, J. R., Lafleur, B., Seebaugh, G. W. R., Wilson, J. C., Gesler, D., Blomquist, B. W., and Fox, J.: PELTI: Measuring the passing efficiency of an airborne low turbulence aerosol inlet, Aerosol Sci. Technol., 38, 803-826, doi:10.1080/027868290500823, 2004.

Huebert, B. J., Phillips, C. A., Zhuang, L., Kjellstrom, E., Rodhe, H., Feichter, J., and Land, C.: Long-term measurements of freetropospheric sulfate at Mauna Loa: Comparison with global model simulations, J. Geophys. Res.-Atmos., 106(D6), 54795492, 2001.

Huffman, J. A., Ziemann, P. J., Jayne, J. T., Worsnop, D. R., and Jimenez, J. L.: Development and Characterization of a Fast-Stepping/Scanning Thermodenuder for ChemicallyResolved Aerosol Volatility Measurements, Aerosol Sci. Technol., 42, 395-407, 2008.

Husar, R. B., Tratt, D. M., Schichtel, B. A., Falke, S. R., Li, F., Jaffe, D., Gasso, S., Gill, T., Laulainen, N. S., Lu, F., Reheis, M. C., Chun, Y., Westphal, D. L., Holben, B. N., Gueymard, C., McKendry, I., Kuring, N., Feldman, G. C., McClain, C. R., Frouin, R., Merrill, C., Dubois, M., Vignola, F., Murayama, T., Nickovic, S., Wilson, W. E., Sassen, K., Sugimoto, N., and Malm, W. C.; Asian dust events of April 1998, J. Geophys. Res., 106(D16), 18317-18330, 2001.

Jacob, D. J.: Heterogeneous chemistry and tropospheric ozone, Atmos. Environ., 34, 2131-2159, 2000.

Jordan, C. E., Dibb, J. E., Anderson, B. E., and Fuelberg, H. E.: Uptake of nitrate and sulfate on dust aerosols during TRACE-P, J. Geophys. Res., 108(D21), GTE 38-1-GTE 38-10, 2003 a.

Jordan, C. E., Dibb, J. E., and Finkel, R. C.: 10 Be/ 7 Be tracer of atmospheric transport and stratosphere-troposphere exchange, $\mathrm{J}$. Geophys. Res., 108(D8), ACL 3-1-ACL 3-14, 2003 b.

Karl, D. M., and Lukas, R. B.: The Hawaii Ocean Time-series (HOT) program: Background, rationale and field implementation, Deep-Sea Res. II, 43, 129-156, 1996.

Kelly, J. T., Chuang, C. C., and Wexler, A. S.: Influence of dust composition on cloud droplet formation, Atmos. Environ., 41, 2904-2916, 2007.

Kim, S., Huey, L. G., Stickel, R. E., Pierce, R. B., Chen, G., Avery, M. A., Dibb, J. E., Diskin, G. S., Sachse, G. W., McNaughton, C. S., Clarke, A. D., Anderson, B. E., and Blake, D. R.: Airborne measurements of $\mathrm{HCl}$ from the marine boundary layer to the lower stratosphere over the North Pacific Ocean during INTEXB, Atmos. Chem. Phys. Discuss., 8, 3563-3595, 2008.

Kim, S., Huey, L. G., Stickel, R. E., Tanner, D. J., Crawford, J. H., Olson, J. R., Chen, G., Brune, W. H., Ren, X., Lesher, R., Wooldridge, P. J., Bertram, T. H., Perring, A. E., Cohen, R. C., Lefer, B., Shetter, R. E., Avery, M., Diskin, G., and Sokolik, I.: Measurement of pernitric acid in the free troposphere, J. Geophys. Res., 112, D12S01, doi:10.1029/2006JD007676, 2007.

Kinne, S., Schulz, M., Textor, C., Guibert, S., Balkanski, Y., Bauer, S. E., Berntsen, T., Berglen, T. F., Boucher, O., Chin, M., Collins, W., Dentener, F., Diehl, T., Easter, R., Feichter, J., Fillmore, D., Ghan, S., Ginoux, P., Gong, S., Grini, A., Hendricks, J., Herzog, M., Horowitz, L., Isaksen, I., Iversen, T., Kirkevåg, A., Kloster, S., Koch, D., Kristjansson, J. E., Krol, M., Lauer, A., Lamarque, J. F., Lesins, G., Liu, X., Lohmann, U., Montanaro, V., Myhre, G., Penner, J., Pitari, G., Reddy, S., Seland, O., Stier, P., Take- mura, T., and Tie, X.: An AeroCom initial assessment - optical properties in aerosol component modules of global models, Atmos. Chem. Phys., 6, 1815-1834, 2006,

http://www.atmos-chem-phys.net/6/1815/2006/.

Kline, J., Huebert, B., Howell, S., Blomquist, B., Zhuang, J., Bertram, T., and Carrillo, J.: Aerosol composition and size versus altitude measured from the C-130 during ACE-Asia, J. Geophys. Res., 109(D19), 1-22, 2004.

Lafon, S., Sokolik, I., Rajot, J., Caquineau, S., and Gaudichet, A.: Characterization of iron oxides in mineral dust aerosols: Implications for light absorption, J. Geophys. Res., 111, D21207, doi:10.1029/2005JD007016, 2006.

Lammel, G., and Novakov, T.: Water nucleation properties of carbon black and diesel soot particles, Atmos. Environ., 29, 813$823,1995$.

Liao, H., and Seinfeld, J. H.: Global impacts of gas-phase chemistry-aerosol interactions on direct radiative forcing by anthropogenic aerosol and ozone, J. Geophys. Res., 110, D18208, doi:10.1029/2005JD005907, 2005.

Liu, T.: Loess in China, China Ocean Press, Beijing, 1985.

Maring, H., Savoie, D. L., Izaguirre, M. A., Custals, L., and Reid, J. S.: Mineral dust aerosol size distribution change during atmospheric transport, J. Geophys. Res., 108(D19), PRD 8-1-PRD 8-6, 2003.

Martin, J. H.: Glacial-interglacial $\mathrm{CO}_{2}$ change: the iron hypothesis, Paleooceanography, 5(1), 1-13, 1990.

Martin, R. V., Jacob, D. J., Yantosca, R. M., Chin, M., and Ginoux, P.: Global and regional decreases in tropospheric oxidants from photochemical effects of aerosols, J. Geophys. Res., 108(D3), 4097, 2003.

Matsuki, A., Schwarzenboeck, A., Venzac, H., Laj, P., Crumeyrolle, S., and Gomes, L.: Effect of surface reaction on the cloud nucleating properties of mineral dust: AMMA aircraft campaign in summer 2006, Atmos. Chem. Phys. Discuss., 9, 1797-1830, 2009.

Mayol-Bracero, O. L., Gabriel, R., Andreae, M. O., Kirchstetter, T. W., Novakov, T., Ogren, J., Sheridan, P., and Streets, D. G.: Carbonaceous aerosols over the Indian Ocean during the Indian Ocean Experiment (INDOEX): Chemical characterization, optical properties, and probable sources, J. Geophys. Res., 107(D19), INX2 29-1-INX2 29-21, 2002.

McNaughton, C. S., Clarke, A. D., Howell, S. G., Pinkerton, M., Anderson, B., Thornhill, L., Hudgins, C., Winstead, E., Dibb, J. E., Scheuer, E., and Maring, H.: Results from the DC-8 Inlet Characterization Experiment (DICE): Airborne versus surface sampling of mineral dust and sea salt aerosols, Aerosol Sci. Technol., 41(2), 136-159, 2007.

Miyazaki, Y., Y. Kondo, N. Takegawa, R.J. Weber, M. Koike, K. Kita, M. Fukuda, Y. Ma, A.D. Clarke, V.N. Kapustin, F. Flocke, A.J. Weinheimer, M. Zondlo, F.L. Eisele, D.R. Blake, and B. Liley, Contribution of particulate nitrate to airborne measurements of total reactive nitrogen, J. Geophys. Res., 110, D15304, doi:10.1029/2004JD005502, 2005.

Moffet, R. C., de Foy, B., Molina, L. T., Molina, M. J., and Prather, K. A.: Measurement ofambient aerosol in northern Mexico City by single particle mass spectrometry, Atmos. Chem. Phys., 8 , 4499-4516, 2008.

Molina, L. T., Madronich, S., Gaffney, J. S., and Singh, H. B.: Overview of MILAGRO/INTEX-B Campaign, IGACtivities 
Newsletter, 38, 2-15, 2008.

Moulin, C., and I. Chiapello, Impact of human-induced desertification on the intensification of Sahel dust emission and export over the last decades, Geophys. Res. Lett., 33, L18808, doi:10.1029/2006GL025923, 2006.

Moya, M., Grutter, M., and Baez, A.: Diurnal variability of sizedifferentiated inorganic aerosol and their gas-phase precursors during January and February of 2003 near downtown Mexico City, Atmos. Environ., 38, 5651-5661, 2004.

Murphy, D. M., Cziczo, D. J., Froyd, K. D., Hudson, P. K., Matthew, B. M., Middlebrook, A. M., Peltier, R. E., Sullivan, A., Thomson, D. S., and Weber, R. J.: Single-particle mass spectrometry of tropospheric aerosol particles, J. Geophys. Res., 111, D23S32, doi:10.1029/2006JD007340, 2006.

Nicholson, S. E., Tucker, C. J., and Ba, M. B.: Desertification, drought, and surface vegetation: An example from the West African Sahel, B. Am. Meteor. Soc., 79(5), 815-829, 1998.

Osborne, S. R. and Haywood, J. M.: Aircraft observations of the microphysical and optical properties of major aerosol species, Atmos. Res., 73, 173-201, 2005.

Penner, J. E., Quaas, J., Storelvmo, T., Takemura, T., Boucher, O., Guo, H., Kirkevåg, A., Kristjánsson, J. E., and Seland, Ø.: Model intercomparison of indirect aerosol effects, Atmos. Chem. Phys., 6, 3391-3405, 2006 http://www.atmos-chem-phys.net/6/3391/2006/.

Petch, J. C.: Using a cloud-resolving model to study the effects of subgrid-scale variations in relative humidity on direct sulphateaerosol forcing, Q. J. Roy. Meteor. Soc., 127(577), 2385-2394, 2001.

Phadnis, M.J., and G.R. Carmichael, Numerical investigation of the influence of mineral dust on the tropospheric chemistry of East Asia, J. Atmos. Chem., 36 (3), 285-323, 2000.

Porter, J. N., and Clarke, A. D.; Aerosol size distribution models based on in situ measurements, J. Geophys. Res.-Atmos., 102(D5), 6035-6045, 1997.

Prospero, J. M.: Long-range transport of mineral dust in the global atmosphere: Impact of African dust on the environment of the southeastern United States, Proc. Nat. Acad. Sci. USA, 96, 33963403, 1999.

Quinn, P. K., Bates, T. S., Baynard, T., Clarke, A. D., Onasch, T., Wang, W., Rood, M. J., Andrews, E., Allan, J., Carrico, C. M., Coffmann, D., and Worsnop, D.: Impact of particulate organic matter on the relative humidity dependence of light scattering: A simplified parameterization, Geophys. Res. Lett., 32, L22809, doi:10.1029/2005GL024322, 2005.

Reid, J. S., Jonsson, H. H., Maring, H. B., Smirnov, A., Savoie, D. L., Cliff, S. S., Reid, E. A., Livingston, J. M., Meier, M. M., Dubovik, O., and Tsay, S. C.: Comparison of size and morphological measurements of coarse mode dust particles from Africa, J. Geophys. Res., 108(D19), PRD 9-1-PRD 9-28, 2003.

Salcedo, D., Onasch, T. B., Dzepina, K., Canagaratna, M. R., Zhang, Q., Huffman, J. A., DeCarlo, P. F., Jayne, J. T., Mortimer, P., Worsnop, D. R., Kolb, C. E., Johnson, K. S., Zuberi, B., Marr, L. C., Volkamer, R., Molina, L. T., Molina, M. J., Cardenas, B., Bernabé, R. M., Márquez, C., Gaffney, J. S., Marley, N. A., Laskin, A., Shutthanandan, V., Xie, Y., Brune, W., Lesher, R., Shirley, T., and Jimenez, J. L.: Characterization of ambient aerosols in Mexico City during the MCMA-2003 campaign with Aerosol Mass Spectrometry: results from the CENICA Super- site, Atmos. Chem. Phys., 6, 925-946, 2006, http://www.atmos-chem-phys.net/6/925/2006/.

Sassen, K.: Indirect climate forcing over the western US from Asian dust storms, Geophys. Res. Lett., 29(10), 1465, 2002.

Sassen, K., DeMott, P. J., Prospero, J. M., and Poellot, M. R.: Saharan dust storms and indirect aerosol effects on clouds: CRYSTAL-FACE results, Geophys. Res. Lett., 30(12), 1633, 2003.

Scheuer, E., Talbot, R. W., Dibb, J. E., Seid, G. K., DeBell, L., and Lefer, B.: Seasonal distributions of fine aerosol sulfate in the North American Arctic basin during TOPSE, J. Geophys. Res., 108(D4), TOP 18-1-TOP 18-11, 2003.

Schnaiter, M., Linke, C., Möhler, O., Naumann, K.-H., Saathoff, H., Wagner, R., Schurath, U., and Wehner, B.: Absorption amplification of black carbon internally mixed iwth secondary organic aerosol, J. Geophys. Res., 110 D19204, doi:10.1029/2005JD006046, 2005.

Seinfeld, J. H. and Pandis, S. N.: Atmospheric chemistry and physics: from air pollution to climate change, John Wiley and Sons, New York, USA, 1998.

Sheehy, D.: A perspective on desertification of grazingland and ecosystems in North China, Ambio, 21, 303-307, 1992.

Singh, H. B., Brune, W. H., Crawford, J. H., Flocke, F., and Jacob, D. J.: Chemistry and transport of pollution over the Gulf of Mexico and the Pacific: spring 2006 INTEX-B campaign overview and first results, Atmos. Chem. Phys., 9, 2301-2318, 2009, http://www.atmos-chem-phys.net/9/2301/2009/.

Sjostedt, S., Huey, L. G., Tanner, D. J., Peischl, J., Chen, G., Dibb, J. E., Lefer, B., Hutterli, M. A., Beyersdorf, A. J., Blake, N. J., Blake, D. R., Sueper, D. T., Ryerson, T. B., Burkhar, J., and Stohl, A.: Observation of hydroxyl and the sum of peroxy radicals at Summit Greenland during summer 2003, Atmos. Environ., 41(24), 5122-5137, doi:10.1016/j.atmosenv.2006.06.065, 2007.

Slowik, J. G., Stainken, K., Davidovits, P., Williams, L. R., Jayne, J. T., Kolb, C. E., Worsnop, D. R., Rudich, Y., DeCarlo, P. F., and Jimenez, J. L.: Particle morphology and density characterization by combined mobility and aerodynamic diameter measurements. Part 2: Application to combustion-generated soot aerosols as a function of fuel equivalence ratio, Aerosol Sci. Technol., 38(12), 1206-1222, 2004

Slusher, D. L., Huey, L. G., Tanner, D. J., Flocke, F. M., and Roberts, J. M.: A thermal dissociation-chemical ionization mass spectrometer (TD-CIMS) technique for the simultaneous measurement of peroxyacul nitrates and dinitrogen pentoxide, J. Geophys. Res., 109, D19315, doi:10.1029/2004JD004670, 2004.

Sokolik, I. N. and Toon, O. B.: Direct radiative forcing by anthropogenic airborne mineral aerosols, Nature, 381, 681-683, 1996.

Sokolik, I. N., and Toon, O. B.: Incorporation of mineralogical composition into models of the radiative properties of mineral aerosol from UV to IR wavelengths, J. Geophys. Res., 104(D8), 9423-9444, 1999.

Solomon, F., Chuang, P. Y., Meskhidze, N., and Chen, Y.: Acidic processing of mineral dust iron by anthropogenic compounds over the North Pacific Ocean, J. Geophys. Res., 114, D02305, doi:10.1029/2008JD010417, 2009.

Song, C. H. and Carmichael, G. R.: Gas-particle partitioning of nitric acid modulated by alkaline aerosol, J. Atmos. Chem., 40(1), $1-22,2001$. 
Stroud, C. A., Nenes, A., Jimenez, J. L., DeCarlo, P. F., Huffman, J. A., Bruintjes, R., Nemitz, E., Delia, A. E., Toohey, D. W., Guenther, A. B., and Nandi, S.: Cloud Activating Properties of Aerosol Observed during CELTIC, J. Atmos. Sci., 65(2), 441459, 2007.

Sullivan, R. C., Guazzotti, S. A., Sodeman, D. A., and Prather, K. A.: Direct observations of the atmospheric processing of Asian mineral dust, Atmos. Chem. Phys., 7, 1213-1226, 2007 a.

Sullivan, R. C., Guazzotti, S. A., Sodeman, D. A., Tang, Y., Carmichael, G. R., and Prather, K. A.: Mineral dust is a sink for chlorine in the marine boundary layer, Atmos. Environ., 41, 7166-7179, 2007b.

Tang, I. N.: Thermodynamic and optical properties of mixed-salt aerosols of atmospheric importance, J. Geophys. Res., 102(D2), 1883-1894, 1997.

Tang, I. N. and Munkelwitz, H. R.: Water activities, densities, and refractive indices of aqueous sulfates and sodium nitrate droplets of atmospheric importance, J. Geophys. Res., 99(D9), 1880118808, 1994.

Tang, I. N., Tridico, A. C., and Fung, K. H.: Thermodynamic and optical properties of sea salt aerosols, J. Geophys. Res., 102(D19), 23269-23276, 1997.

Tang, Y., Carmichael, G. R., Kurata, G., Uno, I., Weber, R., Song, C. H., Guttikunda, S. K., Woo, J. H., Streets, D. G., Wei, C., Clarke, A. D., Huebert, B., and Anderson, T. L.: Impacts of dust on regional tropospheric chemistry during the ACE-Asia experiment: A model study with observations, J. Geophys. Res., 109, D19S21, doi:10.1029/2003JD003806), 2004.

Tegen, I. and Fung, I.: Contribution to the atmospheric mineral aerosol load from land surface modification, J. Geophys. Res., 100(D9), 18707-18726, 1995.

Tegen, I. and Lacis, A. A.: Modeling of particle size distribution and its influence on the radiative properties of mineral dust aerosol, J. Geophys. Res., 101(D14), 19237-19244, 1996.

Tegen, I., Werner, M., Harrison, S. P., and Kohfeld, K. E.: Relative importance of climate and land use in determining present and future global soil dust emission, Geophys. Res. Lett., 31, L05105, doi:10.1029/2003GL019216, 2004.

Textor, C., Schulz, M., Guibert, S., Kinne, S., Balkanski, Y., Bauer, S., Berntsen, T., Berglen, T., Boucher, O., Chin, M., Dentener, F., Diehl, T., Easter, R., Feichter, H., Fillmore, D., Ghan, S., Ginoux, P., Gong, S., Grini, A., Hendricks, J., Horowitz, L., Huang, P., Isaksen, I., Iversen, I., Kloster, S., Koch, D., Kirkevg, A., Kristjansson, J. E., Krol, M., Lauer, A., Lamarque, J. F., Liu, X., Montanaro, V., Myhre, G., Penner, J., Pitari, G., Reddy, S., Seland, ., Stier, P., Takemura, T., and Tie, X.: Analysis and quantification of the diversities of aerosol life cycles within AeroCom, Atmos. Chem. Phys., 6, 1777-1813, 2006, http://www.atmos-chem-phys.net/6/1777/2006/.
Thornton, J. A., Wooldridge, P. J., and Cohen, R. C.: Atmospheric $\mathrm{NO}_{2}$ : In-situ laser-induced fluorescence detection at parts per trillion mixing ratios, Anal. Chem., 72(3), 528-539, 2000.

Twohy, C. H., Kreidenweis, S. M., Eidhammer, T., Browell, E. V., Heymsfield, A. J., Bansemer, A. R., Anderson, B. A., Chen, G., Ismail, S., DeMott, P. J., and Van Den Heever, S. C.: Saharan dust particles nucleate droplets in eastern Atlantic clouds, Geophys. Res. Lett., 36, L01807, doi:10.1029/2008GL035846, 2009.

Ullerstam, C. R., Vogt, R., Langer, S., and Ljungstrom, E.: The kinetics and mechanism of $\mathrm{SO}_{2}$ oxidation by $\mathrm{O}_{3}$ on mineral aerosol, Phys. Chem. Chem. Phys., 4, 4694-4699, 2002.

Underwood, G. M., Song, C. H., Phadnis, M., Carmichael, G. R., and Grassian, V. H.: Heterogeneous reactions of NO2 and HNO3 on oxides and mineral dust: A combined laboratory and modeling study, J. Geophys. Res.-Atmos., 106(D16), 18055-18066, 2001.

Usher, C. R., Al-Hosney, H., Carlos-Cuellar, S., and Grassian, V. H.: A laboratory study of the heterogeneous uptake and oxidation of sulfur dioxide on mineral dust particles, J. Geophys. Res., 107(D23), 4713, doi:10.1029/2002JD002051, 2002.

Virkkula, A., Ahlquist, N. C., Covert, D. S., Arnott, W. P., Sheridan, P. J., Quinn, P. K., and Coffman, D. J.: Modification, Calibration and a Field Test of an Instrument for Measuring Light Absorption by Particles, Aerosol Sci. Technol., 39 1, 68-83, doi:10.1080/027868290901963, 2005.

Wang, Y. Q., Zhang, X. Y., Arimoto, R., Cao, J. J., and Shen, Z. X.: Characteristics of carbonate content and carbon and oxygen isotopic composition of northern China soil and ust aerosol and its application to tracing dust sources, Atmos. Environ., 39, 26312642, 2005.

Weinheimer, A. J., D. D. Montzka, T. L. Campos, et al.: Comparison between DC-8 and ER-2 species measurements in the tropical middle troposphere, J. Geophys. Res., 103(D17), 2208722096, 1998.

Wyslouzil, B. E., Carleton, K. L., Sonnenfroh, D. M., Rawlins, W. T., and Arnold, S.: Observations of hydration of single, modified carbon aerosols, Geophys. Res. Lett., 21, 2107-2110, 1994.

Zimmermann, R., Weinbruch, S., Schutz, L., Hofmann, H., Ebert, M., Kandler, K., and Worringen, A.: Ice nucleation properties of the most abundant mineral dust phases, J. Geophys. Res., 113, D23204, doi:10.1029/2008JD100655, 2008.

Zondlo, M. A., Mauldin, R. L., Kosciuch, E., Cantrell, C. A., and Eisele, F. L.: Development and characterization of an airborne-based instrument used to measure nitric acid during the NASA Transport and Chemical Evolution over the Pacific field experiment, J. Geophys. Res.-Atmos., 108(D20), 8793, doi:10.1029/2002JD003234, 2003. 